\title{
Should stock market return forecasts be conditioned on politics?
}

Australian Journal of Management

(C) The Author(s) 2014

Reprints and permissions: sagepub.co.uk/journalsPermissions.nav DOI: I0.1 |77/03 | 28962|45262। 3 aum.sagepub.com

@SAGE

\section{John G Powell}

Research School of Finance, Actuarial Studies and Applied Statistics, The Australian National University, Australia

\section{Meifen Qian}

International Institute for Financial Studies, Jiangxi University of Finance and Economics, China

\section{Jing Shi}

International Institute for Financial Studies, Jiangxi University of Finance and Economics, China; School of Economics, Finance and Marketing, RMIT University, Australia

\section{Qiaoqiao Zhu}

Research School of Finance, Actuarial Studies and Applied Statistics, The Australian National University, Australia

\begin{abstract}
This paper examines whether stock market returns forecasts should take account of the political party in power by re-examining the prior literature to demonstrate that US stock market political regime differences are neither significant nor long-lasting. We demonstrate that the presidential regime dummy variable used in prior studies is highly auto-correlated, thus potentially violating the ordinary least squares assumption of independently distributed regression errors. Simulation and bootstrap analyses are used to demonstrate that prior findings of higher returns and lower risk under Democratic presidencies are less than would be expected by chance, once account is taken of the persistence properties of the presidential regime dummy variable used in prior studies. Theoretical considerations are also used to explain why presidential regime differences are unlikely to persist, thus further reconciling the paper's findings with prior studies.
\end{abstract}

\section{Keywords}

Auto-correlated explanatory variables, presidential regimes, spurious regression, stock market return differences

\section{Corresponding author:}

Jing Shi, International Institute for Financial Studies, Jiangxi University of Finance and Economics, Jiangxi 3300I3, China. Email: jshi666@gmail.com

Final transcript accepted 9 February 2014 by Tom Smith (AE Finance). 


\section{Introduction}

Recent research documenting stock market risk and return differences under Democratic vs. Republican presidencies is interesting and thought-provoking, especially since it is generally presumed that the Republican Party is the safe bet for stock market investors (Deitrick and Goldfarb, 2012; Leblang and Mukherjee, 2005; Santa-Clara and Valkanov, 2003). Political theorists have therefore been encouraged to explore the theoretical underpinnings of these surprising empirical results, and to examine whether stock market return forecasts should be conditioned on (made dependent upon) the political party in power.

Leblang and Mukherjee (2005) hypothesize that rational expectations of higher inflation under left-leaning governments lower the volatility and mean level of stock returns, with traders anticipating lower dividend growth and thus reduced stock market trading due to higher inflation under Democratic administrations. Gourevitch et al. (2008) theorize, on the other hand, that left-leaning governments adopt policies that benefit the stock market to spur investment and increase the demand for labour. Both papers test their models' implications and find empirical support for their theoretical models, despite the hypotheses of one paper being contrary to the other. This study therefore seeks to resolve these conflicting empirical results, and to answer the overall question of whether stock market return forecasts in the US and Australia should be conditioned on politics. The answer initially depends upon whether monthly or annual data are employed, with excess return differences only being apparent in US monthly data, thus explaining how conflicting results can be obtained in the literature. Subsequent empirical analysis reveals extreme persistence of the US and Australian political party explanatory variable when monthly data are utilized, thus implying that the monthly results appear to be spurious, and no political party return differences are indeed present, while further theoretical analysis explains why a no-difference result is to be expected.

Contrary to the Leblang and Mukherjee (2005) and Gourevitch et al. (2008) stock market theoretical implications, political party stock market hedging considerations and political party theory provide theoretical reasons as to why presidential regime stock market return and return volatility differences are not likely to be significant (see e.g. Miller and Schofield, 2003; Musto and Yilmaz, 2003). The latter consideration, in particular, suggests that the Gourevitch et al. (2008) voter self-interest assumption can be extended by assuming that both the Democratic and Republican parties will (eventually) adopt economic policies that are in the interest of their constituent voters. Each party will thus seek to avoid economic policies that continually harm the stock market and, either directly or indirectly, their party's core voters, implying that poor presidential regime stock market performance is unlikely to persist from one presidential regime to the next, thus further reinforcing the implication that presidential regime differences are unlikely to be statistically significant. These implications are empirically tested using long-term samples of the stock market return and return volatility over presidential terms, with the results indicating that there are no significant return and return volatility differences between Democratic and Republican presidential regimes. Similar results are obtained when Australian political regime differences are examined.

The paper's finding that stock market return and return volatility is indistinguishable between political parties is at odds with some of the recent literature, cited above, documenting risk and return differences under Democratic vs. Republican presidencies (Deitrick and Goldfarb, 2012; Leblang and Mukherjee, 2005; Santa-Clara and Valkanov, 2003). Leblang and Mukherjee (2005), for instance, find a statistically significant negative relationship between the volatility of daily Dow Jones Industrial Average (DJIA) stock market returns and Democratic presidencies during their sample period 1896 to 2001. Santa-Clara and Valkanov 
(2003) find that the Centre for Research in Security Prices (CRSP) value-weighted excess monthly stock market return is $9 \%$ higher per annum under Democratic vs. Republican presidencies, and CRSP equal-weighted returns are 16\% higher during the sample period January 1927 through December $1998 .^{1}$ To explain why this paper's empirical results refute some of the recent empirical literature, the research design of stock market political regime studies is investigated and revisited.

Political regime studies examine whether differences in stock market returns or return volatility can be explained using a dummy explanatory variable that equals 1 if a particular party (e.g. a Democratic president in the US or an Australian Labor Party prime minister) is in power during the observation period, and 0 otherwise. This regression test appears to be straightforward, especially since it is similar to a simple difference in means test and thus apparently innocuous, having been widely used in the political science, economics, and finance literature. What is not so obvious, however, is that a political regime dummy explanatory variable can be highly persistent (i.e. autocorrelated) in time series regression analysis, causing the regression error term to inherit the explanatory variable persistence, and thus violating the ordinary least squares (OLS) assumption of independently distributed regression errors. This causes the standard error of the regression coefficient estimate to be biased downward, and a spurious statistical relationship can occur whereby a significant relationship appears where none is actually present (see Ferson et al., 2003; Granger and Newbold, 1974; Paye, 2006; Yule, 1926). ${ }^{2}$

The regression error persistence problem can be especially serious when daily or monthly return observations are used in political regime studies since the dummy variable run of zeroes or ones will be at least four years for each US presidential regime, and potentially longer for Australian prime ministers, thus inducing extreme explanatory variable persistence. The presidential regime literature is therefore revisited to demonstrate that daily stock return and return volatility differentials between Democratic and Republican presidencies in past studies are statistically indistinguishable once either simulation analysis or a bootstrapping procedure is used to correct statistical inference to take account of the persistence properties of the presidential regime dummy variable. This provides further evidence against rational expectation theoretical models, which imply that stock market returns and return volatility will be lower under Democratic presidencies (see e.g. Leblang and Mukherjee, 2005).

To further reinforce these empirical findings, the theoretical assumptions underpinning the Leblang and Mukherjee (2005) rational expectations model of lower volatility under Democratic presidential regimes are empirically tested, and rejected. Leblang and Mukherjee (2005) hypothesize that traders will rationally anticipate the results of elections, thus leading to reduced stock market trading and therefore return volatility when Democrats are expected to win presidential elections, as investors anticipate lower dividend growth and returns due to higher inflation. The rational expectations model is thus dependent upon higher inflation expectations as well as lower dividend growth, total returns, and trading volume under Democrats. Empirical tests reject the model's assumption that inflation, dividend growth, and trading volume are significantly different under Democratic vs. Republican administrations, thus refuting the assumptions of the Leblang and Mukherjee (2005) model.

The rest of the paper is organized as follows. The first section reviews the empirical and theoretical literature on presidential regime stock market return and return volatility differences. The second section motivates and outlines the empirical tests used in the paper to test for political regime differences, taking account of the influence on statistical inference of the political regime dummy variable that is employed to test for differences. The third section implements the paper's empirical tests on US and Australian samples, and reconciles the test results with the existing presidential regime literature. The final section contains a summary. 


\section{Presidential regime stock market return and volatility differences}

Popular interest in stock market performance under Democratic and Republican presidencies is immense, and is consistently highlighted in well-known periodicals, including The Stock Trader's Almanac (Hirsch and Hirsch, 2005). Academic interest has also been strong, including Herbst and Slinkman (1984), who document a four-year stock market cycle that is related to US presidential elections, and Huang (1985), who finds that stock market returns are almost 10\% per annum higher on average under Democratic vs. Republican presidencies (see also Hensel and Ziemba, 1995).

\section{I. Recent empirical literature}

Santa-Clara and Valkanov (2003) and Leblang and Mukherjee (2005), amongst others, test for Democratic and Republican presidential regime stock return and return volatility differences using a dummy variable regression model. The presidential party dummy variable $D D_{t}$ is set to $D D_{t}=1$ if a Democratic president is in power at time $t$, and $D D_{t}=0$ otherwise. Stock market index return or return volatility $r_{t}$ is regressed on the presidential regime dummy variable using the model

$$
r_{t}=\alpha+\beta D D_{t}+u_{t}
$$

The null hypothesis that presidential regimes are unrelated to stock market returns or return volatility implies $\beta=0$, whereas return or return volatility is higher (lower) under Democratic presidencies if the presidential regime regression coefficient $\beta$ is significantly positive (negative).

Santa-Clara and Valkanov (2003) test the regression model in equation (1) using monthly CRSP value-weighted and equal-weighted stock market excess returns and find that returns are significantly higher under Democratic presidencies in three of the four excess return series they examine during the sample period January 1927 through December 1998. Santa-Clara and Valkanov (2003) control for potential confounding factors such as the business cycle, and extensively examine the robustness of their findings through checks such as sub-sample testing to ascertain the significance of their results.

Leblang and Mukherjee (2005) estimate regression model in equation (1) uses daily capital returns as well as a 20-day rolling volatility estimate for the DJIA during the time period 26 May 1896 through 31 December 2001. Leblang and Mukherjee (2005) find that stock market return volatility is a statistically significant $2 \%$ lower under Democratic vs. Republican administrations, even after carefully controlling for potentially confounding factors such as the presence of divided governments, presidential elections, wars, stock market crashes, and interest rates.

The importance and the surprise element of the Santa-Clara and Valkanov (2003) and Leblang and Mukherjee (2005) findings have not gone unnoticed in the popular press, with a headline in Money.com proclaiming that "Despite 'market friendly' Republican policies, stocks rise more and volatility dips under Democrats” (Twin, 2004). The Santa-Clara and Valkanov (2003) and Leblang and Mukherjee (2005) papers have been cited over 200 times in the popular press, and there has even been a link to the Santa-Clara and Valkanov (2003) paper on the Democratic National Party website, thus indicating the considerable relevance of presidential regime stock market research in the political arena.

More recently, empirical studies have looked at individual stocks rather than the aggregate stock market. These studies indicate that party policies favour or work against particular companies so 
that the companies' stocks can be purchased as potential risk hedges against each party's policies (see e.g. Goldman et al., 2006; Knight, 2006). Knight (2006) provides an ex ante identification of stocks that are more likely to do better under Democratic (Republican) policies, and finds significant out-performance over time by Democratic (Republican) stocks when Gore (Bush) moved ahead in opinion polls during the 2000 presidential election. Goldman et al. (2006) find a similar result for stocks with politically connected board members during the 2000 presidential election year.

\subsection{Theoretical models of political regime return and return volatility differences}

As mentioned above, the importance and the surprise element of the Santa-Clara and Valkanov (2003) and Leblang and Mukherjee (2005) empirical findings regarding presidential regime stock market return and return volatility differences have encouraged political theorists to explore the theoretical underpinnings of these findings.

Leblang and Mukherjee (2005) hypothesize that stock market traders rationally anticipate the results of elections, and expect higher inflation and lower dividend growth when Democrats are expected to win the presidency, thus leading to expectations of poor stock market performance during Democratic presidencies. They also assume that share trading volume will be reduced when Democrats are expected to win office due to the anticipation of poor stock market returns, and further assert that low share trading volumes during Democratic presidencies will be associated with reduced stock market volatility. Leblang and Mukherjee (2005) empirically test theoretical implications of their model using US and British samples, and find share return volatility and share trading volume evidence that is consistent with their rational expectations model.

Gourevitch et al. (2008) reverse the sign of the prevailing explanation of the influence of partisanship on stock markets by theorizing that left-leaning governments, rather than frightening investors (as traditionally argued), instead adopt policies and regulations that will increase the capitalization of the stock market. The resulting financial development leads to higher investment that increases the demand for labour, thus benefiting the supporters of left-leaning political parties. Gourevitch et al. (2008) find that left-leaning governments around the world are associated with higher stock market capitalizations than other governments, as their model predicts. Gourevitch et al. (2008) further argue that the positive correlation they find between left-leaning governments and stock market capitalization is "...consistent with recent theories emphasizing an emerging coalition of workers and owners against managers in favour of greater transparency and shareholder protection" (Gourevitch et al., 2008: 1).

\subsection{Alternative theoretical perspectives implying no regime differences, and hypotheses}

A study by Musto and Yilmaz (2003) helps to provide an alternative theoretical perspective that implies presidential regime risk and return differences are unlikely to be strong and persistent. They analyse the effects of political party redistribution policy within a perfect market equilibrium framework, and find that investor hedging against wealth losses due to potential redistribution policy ameliorates the effects of redistribution policy. This makes it theoretically unlikely that political party redistribution policies would give rise to systematic and persistent effects on investors.

Recent empirical studies on individual stock political effects similarly indicate that party policies favouring or working against particular companies enable their stocks to be purchased as potential risk hedges against each party's policies (see e.g. Goldman et al., 2006; Knight, 2006). The emergence of presidential election prediction markets provides further potential for 
investors to hedge against potential losses due to political party policies (see e.g. Snowberg et al., 2006). In addition, Fowler (2006) points out that presidents will only be able to sufficiently implement policies that have strong effects on investors if they have Congressional support, thus creating policy implementation risk that ameliorates the policy effect. Fowler (2006) also indicates that in the event that election results are predictable, policy effects will be anticipated in advance, thus further dampening post-election policy effects. Due to all of these influences, the net effect of presidential regimes on investors' overall stock market holdings is likely to be close to zero, thus implying that political regime differential effects on the aggregate stock market are likely to be due to chance.

A recent model of voter preferences can also be used to extend the Gourevitch et al. (2008) voter self-interest theory, thus further implying that, contrary to the original Gourevitch et al. (2008) model, political regime differences are most likely to be due to chance. Miller and Schofield (2003) examine political realignments within a game theoretic analysis of disaffected voters. Their analysis implies that if a large group of voters (such as, for the purposes of this paper, a particular group of either economically conservative or economically liberal equity market investors) were consistently made worse off by a party's policies then a political realignment would be a likely outcome. As Schofield et al. (2003) explain, "During most elections there is a stable pattern of partisan cleavages and alliances. Candidates are in equilibrium that allows them to appeal to one set of partisan activists or another. But in certain critical elections, candidates realize that they can improve their electoral prospects by appealing to party activists on new ideological dimensions of politics" (Schofield et al., 2003: 219). By extending the analysis to political regime studies, the implication is that if either the Democratic or the Republican party were to find that their economic and financial policies are consistently making their supporters worse off, they would eventually adapt their policies so that they are in the interest of their constituent voters. ${ }^{3}$ Each party would therefore seek to avoid economic policies that continually harm the stock market and, either directly or indirectly, each party's core voters, thus implying that poor presidential regime stock market performance is unlikely to persist between presidential regimes.

These theoretical and empirical considerations lead to the following testable hypotheses:

Hypothesis 1. Presidential regime stock market return or return volatility differentials are likely to be statistically indistinguishable due to investor hedging, policy implementation considerations, and party policy responses to voter self-interests.

Hypothesis 2. Poor stock market performance is unlikely to persist from one presidential regime to the next, due to investor hedging, policy implementation considerations, and party policy responses to voter self-interests.

In addition to the above theoretical and empirical considerations underpinning hypotheses 1 and 2 , an important statistical issue that is often overlooked is the empirical design of studies examining political regime differences. Given strong persistence of the political regime dummy variable, the regression error term can inherit the persistence and violate the ordinary least squares assumption of independently distributed regression error terms. Regression error persistence can thus create a downward bias in the estimated regression coefficient standard error and the appearance of a significant relationship when there is none. Hence, the empirical results obtained can be spurious and thus potentially indicate a significant statistical relationship when none is actually present, thus implying that it is important to take regression explanatory variable persistence into account when testing hypotheses 1 and 2 . 


\section{Empirical tests of political regime hypotheses}

The presidential regime dummy variable regression equation (1) is used, as in past presidential regime studies, to test whether stock market performance is statistically indistinguishable between Democratic and Republican presidencies (hypothesis 1) and whether poor presidential regime stock market performance does not persist (hypothesis 2). To keep the empirical analysis as close to past studies as possible, long-term CRSP value-weighted stock returns (see e.g. Santa-Clara and Valkanov, 2003) and DJIA stock returns (see Leblang and Mukherjee, 2005) are employed to test presidential regime regression equation (1). Prior to formally testing these hypotheses, regression equation (1) is used to examine a broad range of monthly and annual economic series to provide an initial indication of whether there are economic performance differences between Democratic and Republican presidencies. The data samples are outlined in the following subsection, followed by the hypotheses tests and reconciliation of the test results with the prior presidential regime stock market literature.

\section{I. US data}

An initial analysis is performed on an extensive series of key macroeconomic variables to examine whether there are macroeconomic political regime differences that could underpin stock market return and volatility differences between Democratic and Republican presidencies. The macroeconomic variable data series are obtained from the FRED website at the Federal Reserve Bank of St. Louis, with early NBER series being carefully spliced together to create complete series for all variables from March 1897 through December 2010. As long a sample as possible is utilized to increase the number of distinct presidential regime observations that are used to test the presidential regime hypotheses. An extended sample that includes the history of Republican vs. Democrat presidential elections is therefore used, encompassing presidential elections where the Republicans and Democrats have staked out their parties' positions. For some of the analysis, a stock return data sample is obtained that dates back to 1856 when John C. Fremont became the first Republican nominee for president. For the period January 1926 through December 2004, value-weighted index returns provided by CRSP are used, thus directly matching one of the two (value- and equalweighted CRSP) datasets used by Santa-Clara and Valkanov (2003). For the period January 1857 through December 1925, data are downloaded from http://schwert.ssb.rochester.edu/gws.htm. Schwert (1990) describes in detail the compilation of this stock market return series into a single, continuous share price index series from five historical sources.

Hypotheses 1 and 2 are directly related to the stock return and return volatility during each fouryear presidential regime, so four-year presidential term annualized return and return volatility observations are used to test the hypotheses. Santa-Clara and Valkanov (2003) use monthly stock returns, but there is only one value of the presidential dummy variable observed during each fouryear presidential term, so only the total return and return volatility over the four-year term is relevant (see hypotheses 1 and 2). This approach also has the advantage of greatly reducing persistence problems in the data, as will be discussed below when the results are presented and interpreted (see also Powell et al., 2007). Table 1 provides estimates of the mean and standard deviation of the fouryear annualized presidential regime return and return volatility series, as well as their first-order auto-correlation. The first-order auto-correlation in returns is negative, and return volatility is persistent (see Panel A of Table 1).

Leblang and Mukherjee (2005) test for presidential regime stock return and return volatility differences using the DJIA. In order to further match the stock return samples employed in the presidential regime stock return literature, the DJIA return sample for the time period 4 March 
Table I. Summary statistics on US political regime return and return volatility.

\begin{tabular}{|c|c|c|c|}
\hline Variable & Sample size & Mean & SD \\
\hline
\end{tabular}

Panel A: CRSP value-weighted index

$\begin{array}{lrrrr}\text { Return (\%) } & 37 & 8.670 & 11.155 & -0.509 \\ \text { Volatility (\%) } & 37 & 16.091 & 6.521 & 0.330\end{array}$

Panel B: DJIA index

\begin{tabular}{lrrrr} 
Return (\%) & 26 & 5.613 & 13.378 & -0.506 \\
Volatility (\%) & 26 & 15.965 & 6.372 & 0.316 \\
\hline
\end{tabular}

Panel A reports summary statistics of annualized four-year returns and volatility on the CRSP value-weighted index over four-year intervals, expressed as a percentage. The annualized four-year total returns are expressed as a percentage and are estimated using the monthly returns compiled by Schwert (1990) for the period March 1857 (the inauguration month of James Buchanan) through December 1925, and the CRSP value-weighted index for the period January 1926 through January 2005 (the month of the second inauguration of George W. Bush). The annualized four-year volatility is measured as the annualized standard deviation of returns on the monthly CRSP value-weighted index over the four-year interval, expressed as a percentage. The four-year interval is used in the analysis to minimize the influence of autocorrelation problems in the regression analysis. The data are obtained from CRSP.

Panel B presents descriptive statistics of annualized four-year return and four-year return volatility on the DJIA index over four-year intervals, expressed as a percentage. The annualized four-year total returns are expressed as a percentage and are estimated using the daily DJIA index return over the period 4 March 1897 (the inauguration date of William McKinley) to 19 January 200I (the date before the second inauguration of George W. Bush). Following Leblang and Mukherjee (2005), the annualized four-year volatility is measured as the average annualized 20-day moving standard deviation of return on the daily DJIA index over the four-year interval, expressed as a percentage. The data are obtained from Global Financial Data.

1897 (the inauguration date of William McKinley) to 19 January 2001 (the date before the inauguration of George W. Bush) is obtained from Global Financial Data. Panel B of Table 1 contains summary statistics for annualized four-year returns and the four-year return volatility for the Leblang and Mukherjee (2005) sample period 1897 to 2001. The mean annualized DJIA Index return for the sample is $5.61 \%$ per annum, somewhat lower than the $8.67 \%$ per annum return to the CRSP/Schwert index, but the average annualized return volatility of $16 \%$ per annum for the DJIA index is very similar to the Schwert index volatility (compare Panel B with Panel A of Table 1). Table 1 further reveals that the first-order auto-correlation of returns as well as volatility are very similar for both the DJIA and CRSP/Schwert indices.

\subsection{Return and return volatility hypotheses test results and economic series analysis}

Monthly data descriptive statistics for a wide selection of economic variables are reported in Panels A, B, and C of Table 2 for the sample period March 1897 through December 2010, along with a Democratic president dummy variable $(D D)$ that equals 1 if a Democratic president is in power during a particular month, and 0 otherwise. Panel A reveals that Democratic presidents have been in power roughly $44 \%$ of the time during the sample period. The economic variables have been scrutinized extensively during the post-Second World War time period, and the general features of the economic series for the full sample period, as revealed in Table 2, are quite similar to those that have been widely reported for the more recent sample periods. Table 3 divides the full sample into Democratic vs. Republican sub-samples. Panel C of Table 3 reveals that, when monthly data are used, all of the economic series are significantly higher under Democratic presidencies, when tested using regression equation (1), whereas only one of the three stock return series (EXC, the 
Table 2. Descriptive statistics of US monthly data.

\begin{tabular}{lcllllllll}
\hline Variable & $D D$ & $\begin{array}{l}\text { IP } \\
(\%)\end{array}$ & $\begin{array}{l}G D P \\
(\%)\end{array}$ & $\begin{array}{l}\text { CPI } \\
(\%)\end{array}$ & $\begin{array}{l}\text { NFPR } \\
(\%)\end{array}$ & $\begin{array}{l}R \\
(\%)\end{array}$ & $\begin{array}{l}R R \\
(\%)\end{array}$ & $\begin{array}{l}\text { EXC } \\
(\%)\end{array}$ & $\begin{array}{l}S \\
(\%)\end{array}$ \\
\hline \multicolumn{2}{l}{ Panel A: Descriptive statistics } & & & & & & & \\
Mean & 0.438 & 3.474 & 3.106 & 3.026 & 1.981 & 0.878 & 5.796 & 7.652 & 1.079 \\
Median & 0.000 & 4.048 & 3.282 & 2.661 & 2.194 & 1.215 & 7.900 & 7.973 & 1.060 \\
Maximum & 1.000 & 48.269 & 32.787 & 21.244 & 15.069 & 38.368 & 97.883 & 155.982 & 4.420 \\
Minimum & 0.000 & -41.043 & -35.872 & -17.185 & -12.854 & -29.007 & -96.949 & -66.257 & -8.019 \\
SD & 0.496 & 11.181 & 6.251 & 4.683 & 4.287 & 5.167 & 20.118 & 21.111 & 1.357 \\
Obs. & 1366 & 1366 & 1366 & 1366 & 1366 & 1366 & 1366 & 1366 & 1366
\end{tabular}

Panel B: Auto-correlation

$\begin{array}{rrrrrrrrrr}\text { I } & 0.983 & 0.956 & 0.906 & 0.985 & 0.949 & 0.098 & 0.933 & 0.922 & 0.933 \\ 2 & 0.966 & 0.877 & 0.826 & 0.962 & 0.891 & -0.001 & 0.851 & 0.820 & 0.872 \\ 3 & 0.949 & 0.786 & 0.752 & 0.934 & 0.830 & -0.080 & 0.763 & 0.719 & 0.839 \\ 4 & 0.932 & 0.687 & 0.690 & 0.901 & 0.764 & 0.022 & 0.686 & 0.639 & 0.786 \\ 5 & 0.914 & 0.590 & 0.633 & 0.861 & 0.696 & 0.070 & 0.604 & 0.563 & 0.751 \\ 6 & 0.897 & 0.493 & 0.585 & 0.818 & 0.625 & -0.037 & 0.519 & 0.482 & 0.734\end{array}$

Panel C: Correlations

\begin{tabular}{|c|c|c|c|c|c|c|c|c|c|}
\hline$D D$ & 1.000 & & & & & & & & \\
\hline IP & 0.133 & 1.000 & & & & & & & \\
\hline$B C$ & -0.215 & -0.456 & & & & & & & \\
\hline GDP & 0.112 & 0.715 & 1.000 & & & & & & \\
\hline CPI & 0.244 & 0.201 & 0.167 & 1.000 & & & & & \\
\hline NFPR & 0.113 & 0.753 & 0.755 & 0.398 & 1.000 & & & & \\
\hline$R$ & 0.044 & -0.013 & 0.009 & -0.049 & -0.020 & 1.000 & & & \\
\hline$R R$ & 0.031 & 0.460 & 0.399 & -0.147 & 0.305 & 0.048 & 1.000 & & \\
\hline$E X C$ & 0.113 & 0.494 & 0.426 & -0.011 & 0.348 & 0.046 & 0.966 & 1.000 & \\
\hline$S$ & 0.087 & -0.015 & -0.008 & -0.174 & -0.160 & 0.058 & 0.049 & 0.084 & 1.000 \\
\hline
\end{tabular}

Panel A presents summary statistics for US monthly data over the period March I897 to December 20 I0. DD is I if a Democratic president is in power during a particular month, and 0 otherwise; IP is the I2-month log change in the annualized industrial production index, expressed as a percentage; GDP is the 12-month log change in real gross domestic product, expressed as a percentage; CPI is the I2-month log change in Consumer Price Index, expressed as a percentage; NFPR is the 12-month log change in non-farm payroll, expressed as a percentage; $R$ is the one-month percentage rate of change in the CRSP value-weighted total return index, expressed as a percentage; $R R$ is the difference between the 12-month log change in the CRSP value-weighted total return index and CPI, expressed as a percentage; EXC is the difference between $R$ and the three-month T-bill rate (EXC), expressed as a percentage, and $S$ is the difference between the 10 -year T-bond and three-month T-bill rates, expressed as a percentage.

While Panel B reports auto-correlations of the variables up to six lags, correlations among the variables are presented in Panel C.

excess return difference between the total stock market return and the treasury bill rate) reveals significantly higher stock returns under Democratic presidencies.

Switching the analysis to annual data tells a sharply different story. Descriptive statistics for all the annual series for the full sample are reported in Table 4, with the descriptive statistics corresponding fairly closely to the well-known post-Second World War evidence. When the data sample is divided into Democratic vs. Republican sub-samples in Table 5, however, only the Consumer Price Index (CPI) displays a statistically significant difference, with the inflation rate being twice 


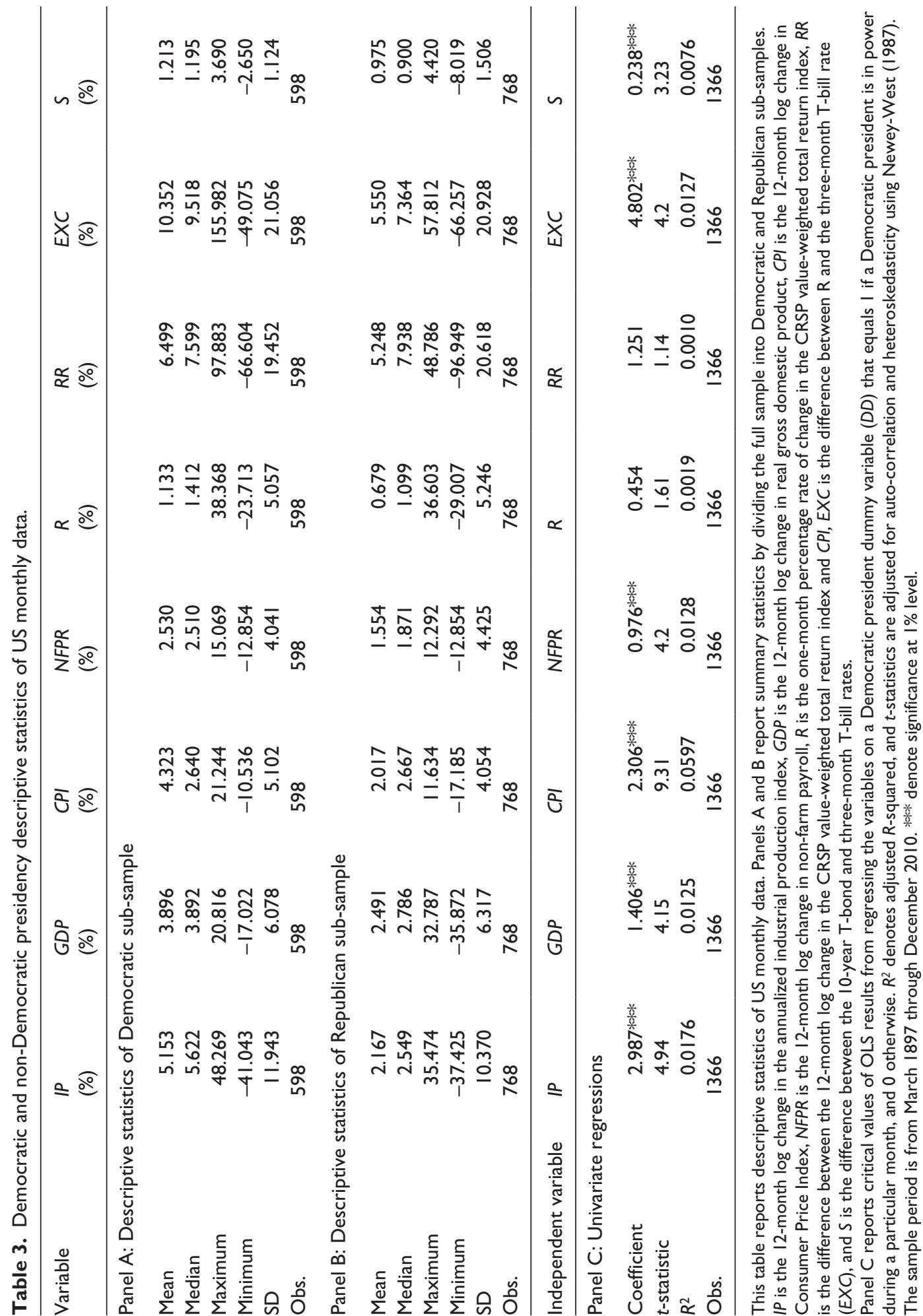


Table 4. Descriptive statistics of US annual data.

\begin{tabular}{llllllllll}
\hline Variable & DD & IP & GDP & CPI & NFPR & $R$ & $R R$ & EXC & $S$ \\
& & $(\%)$ & $(\%)$ & $(\%)$ & $(\%)$ & $(\%)$ & $(\%)$ & $(\%)$
\end{tabular}

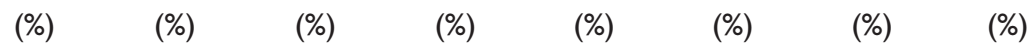

Panel A: Descriptive statistics

$\begin{array}{lrrrrrrrrr}\text { Mean } & 0.434 & 3.415 & 3.050 & 3.043 & 1.971 & 8.867 & 5.824 & 7.689 & 1.120 \\ \text { Median } & 0.000 & 3.612 & 3.248 & 2.691 & 2.194 & 12.218 & 8.946 & 8.609 & 0.939 \\ \text { Maximum } & 1.000 & 26.749 & 20.181 & 18.540 & 10.632 & 56.657 & 52.040 & 75.600 & 3.670 \\ \text { Minimum } & 0.000 & -36.560 & -13.187 & -10.749 & -12.854 & -65.772 & -55.023 & -50.852 & -2.450 \\ \text { SD } & 0.498 & 11.029 & 5.929 & 4.667 & 4.259 & 19.665 & 19.804 & 20.683 & 1.214 \\ \text { Obs. } & 113 & 113 & 113 & 113 & 113 & 113 & 113 & 113 & 113\end{array}$

Panel B: Auto-correlation

$\begin{array}{rrrrrrrrrr}I & 0.793 & -0.067 & 0.266 & 0.548 & 0.244 & 0.004 & -0.004 & -0.043 & 0.594 \\ 2 & 0.606 & -0.155 & 0.029 & 0.196 & -0.151 & -0.189 & -0.185 & -0.184 & 0.269 \\ 3 & 0.419 & 0.024 & -0.186 & 0.085 & -0.120 & 0.024 & 0.026 & 0.026 & 0.103 \\ 4 & 0.232 & -0.051 & -0.191 & 0.091 & -0.172 & -0.068 & -0.032 & -0.059 & 0.036 \\ 5 & 0.081 & -0.177 & -0.156 & 0.131 & -0.110 & -0.136 & -0.098 & -0.108 & 0.114 \\ 6 & -0.070 & 0.045 & 0.075 & 0.147 & 0.167 & 0.013 & 0.031 & -0.006 & 0.192\end{array}$

Panel C: Correlations

\begin{tabular}{|c|c|c|c|c|c|c|c|c|c|}
\hline$D D$ & 1.000 & & & & & & & & \\
\hline$I P$ & 0.122 & 1.000 & & & & & & & \\
\hline$B C$ & -0.266 & -0.605 & & & & & & & \\
\hline$R B C$ & -0.203 & -0.623 & & & & & & & \\
\hline$B C M$ & -0.306 & -0.392 & & & & & & & \\
\hline GDP & 0.141 & 0.753 & 1.000 & & & & & & \\
\hline$C P I$ & 0.263 & 0.244 & 0.122 & 1.000 & & & & & \\
\hline NFPR & 0.096 & 0.820 & 0.756 & 0.304 & 1.000 & & & & \\
\hline$R$ & 0.122 & 0.495 & 0.533 & 0.089 & 0.462 & 1.000 & & & \\
\hline$R R$ & 0.059 & 0.434 & 0.500 & -0.147 & 0.388 & 0.972 & 1.000 & & \\
\hline$E X C$ & 0.134 & 0.472 & 0.537 & 0.005 & 0.424 & 0.975 & 0.968 & 1.000 & \\
\hline$S$ & -0.037 & 0.049 & 0.113 & -0.180 & -0.052 & 0.046 & 0.088 & 0.121 & 1.000 \\
\hline
\end{tabular}

Panel A presents summary statistics for US Annual data over the period I897 to 2010. DD is I if a Democratic president is in power during a particular month, and 0 otherwise; IP is the one-year log change in the annualized industrial production index; GDP is the one-year log change in real gross domestic product; CPI is the one-year log change in Consumer Price Index; NFPR is the one-year log change in non-farm payroll; $R$ is the one-year log change in the CRSP value-weighted total return index; $R R$ is the difference between the one-year log change in the CRSP value-weighted total return index and CPI; EXC is the difference between one-year rate of change in the CRSP value-weighted total return index and the three-month T-bill rate; and $S$ is the difference between the 10 -year T-bond and three-month T-bill rates. Panel $\mathrm{B}$ reports auto-correlations of the variables up to six lags; correlations among the variables are presented in Panel $\mathrm{C}$.

as high under Democratic vs. Republican presidencies during the sample period 1897 through 2010. None of the other economic and stock return series display statistically significant differences.

What is the reason for the sharp distinction between the statistical significance of the results when using monthly vs. annual data? One factor can provide an explanation. It is the extreme persistence of the monthly Democratic presidency dummy variable $(D D)$ explanatory variable, used to test for presidential regime differences in Table 3, as revealed in Panel B of Table 3. 
Table 5. Democratic and non-Democratic presidency descriptive statistics of US annual data.

\begin{tabular}{|c|c|c|c|c|c|c|c|c|}
\hline Variable & $\begin{array}{l}\text { IP } \\
(\%)\end{array}$ & $\begin{array}{l}\text { GDP } \\
(\%)\end{array}$ & $\begin{array}{l}\text { CPI } \\
(\%)\end{array}$ & $\begin{array}{l}\text { NFPR } \\
(\%)\end{array}$ & $\begin{array}{l}R \\
(\%)\end{array}$ & $\begin{array}{l}R R \\
\text { (\%) }\end{array}$ & $\begin{array}{l}\text { EXC } \\
(\%)\end{array}$ & $\begin{array}{l}S \\
(\%)\end{array}$ \\
\hline \multicolumn{9}{|c|}{ Panel A: Descriptive statistics of Democratic sub-sample } \\
\hline Mean & 4.941 & 4.003 & 4.439 & 2.438 & 11.595 & 7.156 & 10.853 & 1.069 \\
\hline Median & 5.202 & 3.725 & 2.702 & 2.474 & 13.654 & 8.946 & 11.333 & 0.920 \\
\hline Maximum & 26.749 & 20.181 & 18.540 & 10.632 & 56.657 & 52.040 & 75.600 & 3.670 \\
\hline Minimum & -36.560 & $-|2.49|$ & -5.806 & -12.854 & -42.481 & -43.188 & -34.711 & -2.450 \\
\hline SD & $|3.15|$ & 6.448 & 5.214 & 4.510 & 17.846 & 18.905 & 20.275 & 1.125 \\
\hline Obs. & 49 & 49 & 49 & 49 & 49 & 49 & 49 & 49 \\
\hline
\end{tabular}

Panel B: Descriptive statistics of Republican sub-sample

\begin{tabular}{lrrrrrrrl} 
Mean & 2.246 & 2.321 & 1.974 & 1.613 & 6.778 & 4.804 & 5.266 & 1.159 \\
Median & 2.854 & 2.480 & 2.582 & 1.804 & 8.999 & 7.381 & 6.272 & 0.964 \\
Maximum & 26.510 & 17.595 & 11.156 & 10.071 & 40.664 & 41.410 & 48.956 & 3.620 \\
Minimum & -22.996 & -13.187 & -10.749 & -12.690 & -65.772 & -55.023 & -50.852 & -1.748 \\
SD & 9.015 & 5.437 & 3.915 & 4.056 & 20.847 & 20.554 & 20.822 & 1.286 \\
Obs. & 64 & 64 & 64 & 64 & 64 & 64 & 64 & 64 \\
\hline Independent & IP & GDP & CPI & NFPR & $R$ & RR & EXC & $S$ \\
variable & & & & & & & & \\
\hline
\end{tabular}

Panel C: Univariate regressions

\begin{tabular}{lllllllll} 
Coefficient & 2.696 & $1.68 \mathrm{I}$ & $2.465^{* *}$ & 0.825 & 4.817 & 2.352 & $5.587^{*}$ & -0.090 \\
$t$-statistic & 1.4 & 1.29 & 2.02 & 0.94 & 1.49 & 0.7 & 1.69 & -0.27 \\
$R^{2}$ & 0.0059 & 0.0111 & 0.0608 & 0.0004 & 0.006 & -0.0055 & 0.0092 & -0.0076 \\
Obs. & 113 & 113 & 113 & 113 & 113 & 113 & 113 & 113 \\
\hline
\end{tabular}

This table reports descriptive statistics of US annual data. Panels A and B report summary statistics by dividing the full sample into Democratic and Republican sub-samples. IP is the one-year log change in the annualized industrial production index; GDP is the one-year log change in real gross domestic product; CPI is the one-year log change in Consumer Price Index; NFPR is the one-year log change in non-farm payroll; $R$ is the one-year log change in the CRSP value-weighted total return index; $R R$ is the difference between the one-year log change in the CRSP value-weighted total return index and CPI; EXC is the difference between one-year rate of change in the CRSP value-weighted total return index and the three-month T-bill rate; and $S$ is the difference between the I0-year T-bond and three-month T-bill rates. The sample period is I897 through 2010. Panel C reports critical values of OLS results from regressing the variables on a Democratic president dummy variable $(D D)$ that equals I if a Democratic president is in power during a particular month, and 0 otherwise. $R^{2}$ denotes adjusted $R$-squared, and $t$-statistics are adjusted for auto-correlation and heteroskedasticity using Newey-West (I987). $*^{*}$ and $*$ denote significance at $5 \%$ and $10 \%$ levels, respectively.

The persistence of the Democratic presidential dummy variable is greatly reduced when annual data are employed. For instance, the first-order auto-correlation of $D D$ decreases from 0.983 in the monthly data to 0.793 in the annual data. This provides an initial indication that any differences found using monthly data may be spurious, and due to extreme persistence (note also the very low $R$-squares reported in Panel C of Table 3 of approximately 1\% for most tests for differences). This possibility of spurious regression is explored more formally below.

CRSP value-weighted and DJIA Index return and return volatility results for presidential regime regression model (1) are reported in Panels A and B, respectively, of Table 6. The dependent variable in Table 6 is the annualized four-year presidential regime return or return volatility for the CRSP/Schwert and DJIA samples, respectively, and the independent variable is the Democratic president dummy 
Table 6. US political regime return and volatility differential regression results under four-year intervals.

\begin{tabular}{|c|c|c|c|c|c|}
\hline & $\alpha$ & $t(\alpha)$ & $\beta$ & $t(\beta)$ & $\bar{R}^{2}(\%)$ \\
\hline \multicolumn{6}{|c|}{ Panel A: CRSP value-weighted index } \\
\hline Return (\%) & $7.780 * * *$ & 4.067 & 2.197 & 0.767 & -1.87 \\
\hline Volatility (\%) & $15.512 * * *$ & 11.568 & 1.428 & 0.933 & -1.64 \\
\hline \multicolumn{6}{|c|}{ Panel B: DJIA index } \\
\hline Return (\%) & 4.205 & 1.266 & 3.051 & 0.657 & -2.77 \\
\hline Volatility (\%) & $16.653 * * *$ & 8.805 & -1.490 & -0.893 & -2.69 \\
\hline
\end{tabular}

The table reports OLS regression of annualized four-year differential returns and volatility on the presidential dummy variable

$$
y_{t}=\alpha+\beta D D_{t}+u
$$

where $y_{t}$ denotes annualized four-year return and volatility over four-year interval $t$, expressed as a percentage; and $D D_{t}$ is $I$ if a Democrat is in office at time $t$ (i.e. the beginning of the term), and 0 otherwise. The four-year interval is used in the analysis to minimize the influence of auto-correlation problems in the regression analysis. Regressions are estimated by OLS, and $t$-statistics are adjusted for auto-correlation and heteroskedasticity using Newey-West (I987). $\bar{R}^{2}$ denotes

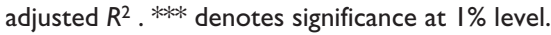

Panel A reports the results of annualized four-year return and volatility on the CRSP value-weighted index over the four-year interval. The annualized four-year returns are expressed as a percentage and are estimated using the monthly returns compiled by Schwert (1990) for the period March 1857 (the inauguration month of James Buchanan) through December 1925 and the CRSP value-weighted index for the period January 1926 through January 2005 (the month of the second inauguration of George W. Bush). The annualized four-year volatility is measured as the annualized standard deviation of returns on the monthly CRSP value-weighted index over the four-year interval, expressed as a percentage. The data are obtained from CRSP.

Panel B presents the regression results of annualized four-year return and volatility on the DJIA index over the fouryear interval $t$. The annualized four-year returns are expressed as a percentage and are estimated using the daily DJIA index return over the period 4 March 1897 (the inauguration date of William McKinley) to I9 January 200 I (the date before the second inauguration of George W. Bush). Following Leblang and Mukherjee (2005), the annualized four-year volatility is measured as the average annualized 20-day moving standard deviation of return on the daily DJIA index over the four-year interval, expressed as a percentage. The data are obtained from Global Financial Data.

variable $D D_{\mathrm{t}}$ which equals 1 if a Democrat is president during the observation period, and 0 otherwise. The regression dummy variable is constructed using the presidential election result summary provided in Appendix 1. Both data samples indicate that there are no significant return or return volatility differences between Democratic vs. Republican presidential regimes, since the presidential dummy variable coefficient estimate $\beta$ in Table 6 is insignificantly different from 0 in all four regression tests. The Table 6 results are therefore consistent with hypothesis 1 , which implies that stock market performance will be statistically indistinguishable between Democratic and Republican presidencies.

A similar story emerges when political regime regression model (1) is applied to Australian data, as reported in Tables 7 and $8 .{ }^{4}$ Once again, in Table 7 , monthly data descriptive statistics for a wide selection of economic variables are reported. The sample period is October 1923 through September 2013, a sample period when the Australian Labor Party and the Liberal Party or its right-of-centre antecedents have either been in power or leading the opposition. ${ }^{5}$ The political regime dummy variable $(D D)$ in regression equation (1) in Table 7 is adapted so that it equals 1 if a Labor Party prime minister is in power during a particular month, and 0 otherwise. Table 8 is equivalent to Table 7, but uses annual data, with the political regime dummy variable (DD) equalling 1 if a Labor Party prime minister is in power during most of the year, and 0 otherwise. When monthly data are employed in Table 7 , the political regime dummy variable once again significantly explains real returns $R R$ (see Panel E), but this time the left-of-centre party actually has 
lower returns! The real return regression coefficient estimate $(R R)$ becomes insignificant, however, when annual data is employed in Table 8 . Once again, the political regime dummy variable $(D D)$ is extremely persistent when monthly data are examined (0.981 in Panel B of Table 7), thus suggesting that the Australian monthly political regime results are potentially spurious, especially since the significance disappears when less persistent annual data are used.

The US results (Table 6) are in sharp contrast to the significant presidential regime return and return volatility differentials found by Santa-Clara and Valkanov (2003) and Leblang and Mukherjee (2005), where monthly and daily data samples are used, respectively, rather than the four-year

Table 7. Descriptive statistics of Australian monthly data.

\begin{tabular}{lccccccccr}
\hline Variable & DD & $I P$ & GDP & CPI & NFPR & \multicolumn{1}{c}{$R$} & $R R$ & EXC & \multicolumn{1}{c}{$S$} \\
\hline Panel A: Descriptive statistics & & & & & & & \\
Mean & 0.355 & 2.249 & 3.484 & 5.188 & 2.052 & 0.568 & 1.090 & -0.611 & 0.818 \\
Median & 0.000 & 2.357 & 3.521 & 3.650 & 2.205 & 0.604 & 3.310 & 0.424 & 0.995 \\
Maximum & 1.000 & 12.095 & 8.673 & 16.209 & 5.316 & 22.269 & 51.281 & 47.756 & 5.586 \\
Minimum & 0.000 & -8.322 & -3.377 & -0.334 & -2.521 & -42.446 & -71.868 & -60.467 & -4.805 \\
SD & 0.479 & 3.151 & 2.161 & 3.691 & 1.680 & 4.231 & 20.532 & 18.809 & 1.774 \\
Obs. & 1088 & 414 & 636 & 588 & 285 & 1088 & 588 & 333 & 333
\end{tabular}

Panel B: Auto-correlation

\begin{tabular}{rrrrrrrrrr}
$I$ & 0.981 & 0.907 & 0.901 & 0.986 & 0.957 & 0.094 & 0.932 & 0.903 & 0.954 \\
2 & 0.962 & 0.814 & 0.801 & 0.973 & 0.915 & 0.005 & 0.852 & 0.790 & 0.873 \\
3 & 0.943 & 0.721 & 0.702 & 0.959 & 0.872 & 0.033 & 0.765 & 0.676 & 0.784 \\
4 & 0.923 & 0.608 & 0.628 & 0.942 & 0.812 & 0.030 & 0.680 & 0.574 & 0.722 \\
5 & 0.904 & 0.495 & 0.555 & 0.926 & 0.752 & -0.037 & 0.596 & 0.468 & 0.667 \\
6 & 0.885 & 0.382 & 0.482 & 0.909 & 0.692 & 0.003 & 0.520 & 0.371 & 0.616 \\
\hline & $I P$ & GDP & CPI & NFPR & \multirow{2}{*}{$R$} & \multirow{2}{*}{ RR } & \multirow{2}{*}{ EXC } & $S$ \\
\hline
\end{tabular}

Panel C: Descriptive statistics of Labor sub-sample

\begin{tabular}{lcclrrrrr} 
Mean & 2.582 & 3.043 & 5.801 & 1.894 & 0.385 & -2.590 & -0.560 & 0.703 \\
Median & 2.783 & 3.270 & 4.930 & 2.252 & 0.296 & -1.486 & -2.307 & 0.828 \\
Maximum & 12.095 & 7.820 & 16.209 & 5.316 & 22.269 & $51.28 I$ & 47.756 & 5.586 \\
Minimum & -8.322 & -3.377 & 0.278 & -2.521 & -42.446 & -71.868 & -50.165 & -4.805 \\
SD & 3.683 & 2.098 & 3.826 & 2.125 & 5.251 & 24.122 & 18.698 & 2.127 \\
Obs. & 208 & 258 & 243 & 144 & 386 & 243 & 207 & 207 \\
\hline & IP & \multirow{2}{*}{ GDP } & CPI & NFPR & \multirow{2}{*}{ R } & \multirow{2}{*}{ RR } & \multirow{2}{*}{ EXC } & \multirow{2}{*}{$S$} \\
\hline
\end{tabular}

Panel D: Descriptive statistics of Liberal/right-of-centre sub-sample

$\begin{array}{lrrrrrrrr}\text { Mean } & 1.914 & 3.786 & 4.756 & 2.214 & 0.668 & 3.682 & -0.695 & 1.008 \\ \text { Median } & 2.118 & 3.843 & 3.139 & 2.205 & 0.706 & 5.601 & 1.884 & 1.159 \\ \text { Maximum } & 6.854 & 8.673 & 13.448 & 4.505 & 18.203 & 50.059 & 36.602 & 3.042 \\ \text { Minimum } & -8.322 & -2.524 & -0.334 & -0.009 & -13.832 & -52.727 & -60.467 & -4.536 \\ \text { SD } & 2.467 & 2.192 & 3.535 & 1.031 & 3.547 & 17.137 & 19.065 & 0.922 \\ \text { Obs. } & 206 & 378 & 345 & 141 & 702 & 345 & 126 & 126\end{array}$


Table 7. (Continued)

\begin{tabular}{lclllllll}
\hline & IP & GDP & CPI & NFPR & $R$ & $R R$ & EXC & $S$ \\
\hline Panel E: Univariate regressions & & & & & & & \\
Coefficient & 0.668 & $-0.744^{* *}$ & $1.045^{*}$ & -0.320 & -0.283 & $-6.273^{*}$ & 0.135 & -0.305 \\
$t$-statistic & -1.19 & -2.36 & 1.71 & -0.84 & -0.88 & -1.83 & 0.03 & -0.97 \\
$R^{2}$ & 0.0088 & 0.0271 & 0.0178 & 0.0056 & 0.0001 & 0.0210 & -0.0030 & 0.0040 \\
Obs. & 414 & 636 & 588 & 285 & 1088 & 588 & 333 & 333 \\
\hline
\end{tabular}

Panel A presents summary statistics for Australian monthly data over the period October I923 to September 20I3. DD is I if a Labor prime minister is in power during a particular month, and zero otherwise; IP is the I2-month log change in the industrial production index, expressed as a percentage; GDP is the 12-month log change in real gross domestic product, expressed as a percentage; CPI is the I2-month log change in Consumer Price Index, expressed as a percentage; NFPR is the 12-month log change in non-farm payroll, expressed as a percentage; $R$ is the one-month percentage rate of change in the ASX All Ordinaries Index, expressed as a percentage; $R R$ is the difference between the I2-month log change in the ASX All Ordinaries Index and CPI, expressed as a percentage; EXC is the difference between I2-month log change in the ASX All Ordinaries Index and the three-month T-bill rate (EXC), expressed as a percentage; and $S$ is the difference between the 10 -year T-bond and three-month T-bill rates, expressed as a percentage.

While Panel B reports auto-correlations of the variables up to six lags, Panel C and Panel D report summary statistics by dividing the full sample into Labor and Liberal/right-of-centre sub-samples. Panel E reports critical values of OLS results from regressing the variables on a Labor prime minister dummy variable (DD). $R^{2}$ denotes adjusted $R$-squared, and $t$-statistics are adjusted for auto-correlation and heteroskedasticity using Newey-West (1987). * and ** denote significance at $10 \%$ and $5 \%$ levels, respectively.

Table 8. Descriptive statistics of Australian annual data.

\begin{tabular}{lccccccccr}
\hline Variable & DD & \multicolumn{1}{l}{ IP } & GDP & \multicolumn{1}{l}{ CPI } & NFPR & \multicolumn{1}{l}{$R$} & $R R$ & EXC & \multicolumn{1}{l}{$S$} \\
\hline Panel A: Descriptive statistics & & & & & & & \\
Mean & 0.378 & 2.253 & 3.500 & 5.191 & 2.061 & 5.638 & 0.943 & -0.006 & 0.807 \\
Median & 0.000 & 2.483 & 3.552 & 3.461 & 2.023 & 8.523 & 5.349 & 2.515 & 1.244 \\
Maximum & 1.000 & 12.095 & 7.836 & 15.100 & 5.039 & 46.828 & 38.556 & 38.913 & 5.586 \\
Minimum & 0.000 & -7.034 & -2.340 & -0.250 & -2.247 & -53.262 & -56.881 & -37.378 & -4.511 \\
SD & 0.488 & 3.107 & 2.143 & 3.776 & 1.702 & 17.941 & 22.319 & 19.777 & 2.091 \\
Obs. & 90 & 35 & 52 & 49 & 24 & 90 & 49 & 28 & 28
\end{tabular}

Panel B: Auto-correlation

\begin{tabular}{|c|c|c|c|c|c|c|c|c|}
\hline 0.775 & -0.088 & 0.036 & 0.777 & 0.280 & -0.120 & -0.134 & -0.353 & 0.293 \\
\hline 0.550 & -0.104 & -0.004 & 0.602 & -0.244 & -0.154 & -0.145 & -0.138 & -0.322 \\
\hline 0.324 & -0.103 & 0.025 & 0.503 & -0.379 & 0.059 & 0.096 & 0.084 & -0.079 \\
\hline 0.194 & -0.035 & -0.011 & 0.417 & -0.221 & -0.096 & -0.102 & -0.259 & 0.159 \\
\hline 0.063 & -0.197 & 0.179 & 0.391 & 0.136 & -0.053 & -0.036 & 0.018 & -0.145 \\
\hline-0.068 & 0.033 & -0.146 & 0.340 & 0.149 & -0.105 & -0.055 & 0.209 & -0.389 \\
\hline & & & & & & $R R$ & $E X C$ & $S$ \\
\hline
\end{tabular}

Panel C: Descriptive statistics of Labor sub-sample

\begin{tabular}{lrrrrrrrr} 
Mean & 2.759 & 3.079 & 5.414 & 1.994 & 2.326 & -2.324 & 0.942 & 0.578 \\
Median & 2.761 & 3.447 & 4.581 & 2.252 & 6.628 & 2.843 & -2.829 & 0.950 \\
Maximum & 12.095 & 6.232 & 15.100 & 5.039 & 46.828 & 38.556 & 38.913 & 5.586 \\
Minimum & -1.066 & -1.155 & 0.278 & -2.247 & -53.262 & -56.881 & -37.378 & -4.511 \\
SD & 3.175 & 1.950 & 3.781 & 2.210 & 22.916 & 27.929 & 21.368 & 2.604 \\
Obs. & 18 & 21 & 21 & 13 & 34 & 21 & 17 & 17 \\
\hline
\end{tabular}


Table 8. (Continued)

\begin{tabular}{|c|c|c|c|c|c|c|c|c|}
\hline & IP & GDP & CPI & NFPR & $R$ & $R R$ & EXC & $S$ \\
\hline \multicolumn{9}{|c|}{ Panel D: Descriptive statistics of Liberal/right-of-centre sub-sample } \\
\hline Mean & 1.718 & 3.786 & 5.023 & 2.140 & 7.649 & 3.394 & $-1.47 \mid$ & 1.161 \\
\hline Median & 2.317 & 3.955 & 3.168 & 1.967 & 8.523 & 5.643 & 2.653 & 1.314 \\
\hline Maximum & 6.492 & 7.836 & 13.448 & 3.622 & 39.899 & 27.179 & 23.378 & 2.355 \\
\hline Minimum & -7.034 & -2.340 & -0.250 & 0.710 & -23.656 & -30.924 & -32.088 & -0.545 \\
\hline SD & 3.035 & 2.250 & 3.832 & 0.891 & 13.959 & 17.124 & 17.934 & 0.856 \\
\hline Obs. & 17 & 31 & 28 & 11 & 56 & 28 & II & II \\
\hline \multicolumn{9}{|c|}{ Panel E: Univariate regressions } \\
\hline Coefficient & 1.041 & -0.07 & 0.391 & -0.146 & -5.323 & -5.717 & 2.413 & -0.584 \\
\hline t-statistic & 1.19 & -1.34 & 0.23 & -0.22 & -1.45 & -1.07 & 0.45 & -0.87 \\
\hline$R^{2}$ & -0.0005 & 0.0072 & -0.0185 & -0.0435 & 0.0098 & -0.0045 & -0.0346 & -0.0134 \\
\hline Obs. & 35 & 52 & 49 & 24 & 90 & 49 & 28 & 28 \\
\hline
\end{tabular}

Panel A presents summary statistics for Australian annual data over the period I 923 to 2012 . The variables are as described in Table 3, except $R$ is the 12-month log return in the ASX All Ordinaries Index. Panel B reports auto-correlations of the variables up to six lags. Panel $C$ and Panel $D$ report summary statistics by dividing the full sample into Labor and Liberal/rightof-centre sub-samples. Panel E reports critical values of OLS results from regressing the variables on a Labor prime minister dummy variable $(D D) . R^{2}$ denotes adjusted $R$-squared, and $t$-statistics are adjusted for auto-correlation and heteroskedasticity using Newey-West (1987).

return and return volatility observations used in this paper's study. The contrast in results emphasizes the data persistence problems that are encountered when monthly and daily data samples are employed in presidential regime studies, as will be demonstrated below to reconcile the results of Table 6 with the prior presidential regime literature, once hypothesis 2 is tested.

A test of hypothesis 2, used to examine whether poor presidential regime stock market performance is unlikely to persist, can be conducted by adapting presidential regime regression model (1) to provide further evidence in support of the dynamic activist voter model implications. To test hypothesis 2 , presidential regime regression model (1) is modified to

$$
r_{t}=\alpha+\beta_{1} D B_{t-1}+\beta_{2} R B_{t-1}+u_{t}
$$

where $r_{t}$ is the four-year annualized presidential regime stock return, and the dummy variable $D B_{t-1}$ $\left(R B_{t-1}\right)=1$ if a Democrat (Republican) president is in power and returns were below average during the prior Democratic (Republican) presidential regime (and 0 otherwise). The null hypothesis that poor stock market performance does not persist from one president to the next president from the same party implies $\beta_{1}=0$ and $\beta_{2}=0$, whereas poor stock market performance persists amongst Democratic (Republican) presidencies if $\beta_{1}<0\left(\beta_{2}<0\right)$.

Results for various configurations of regression model (2) are presented in Table 9 where the annualised four-year presidential regime return is used. All the prior presidential performance dummy variable regression coefficient estimates are insignificantly different from $0\left(\beta_{1}=0\right.$ and $\beta_{2}=0$ ). Table 9 thus provides results that are consistent with hypothesis 2 , since poor presidential regime performance is shown to be non-persistent. The Table 9 results are therefore consistent with 
Table 9. Regression results of annualized four-year differential returns in the US.

\begin{tabular}{|c|c|c|c|c|c|c|}
\hline & \multicolumn{2}{|l|}{ Model I } & \multicolumn{2}{|l|}{ Model 2} & \multicolumn{2}{|l|}{ Model 3} \\
\hline & Coefficient. & $t$-statistic & Coefficient. & $t$-statistic & Coefficient. & $t$-statistic \\
\hline \multicolumn{7}{|c|}{ Panel A: CRSP value-weighted index } \\
\hline Constant & $7.647 * * *$ & 4.413 & $7.919 * * *$ & 5.357 & $6.343 * *$ & 2.665 \\
\hline$D B$ & 6.310 & 1.133 & & & 7.614 & 1.267 \\
\hline$R B$ & & & 3.476 & 1.304 & 5.052 & 1.472 \\
\hline \multicolumn{7}{|c|}{ Panel B: DJIA index } \\
\hline Constant & 14.604 & 1.466 & $21.757^{* *}$ & 2.672 & 12.017 & 0.882 \\
\hline$D B$ & 31.504 & 1.345 & & & 34.091 & 1.284 \\
\hline$R B$ & & & -0.685 & -0.053 & 9.055 & 0.518 \\
\hline
\end{tabular}

The table reports OLS regression of annualized four-year differential returns on the dummy variables

$$
y_{t}=\beta_{0}+\beta_{1}(D B)_{t}+\beta_{2}(R B)_{t}+u_{t}
$$

where $r_{t}$ denotes annualized four-year return of the DJIA index over the four-year interval $t$, expressed as a percentage; $D B$ is equal to $I$ if Democrats had a below average return when they were last in power and they are in power again, and 0 otherwise; $R B$ is equal to I if Republicans had a below average return when they were last in power and they are in power again, and 0 otherwise. The four-year interval is used in the analysis to minimize the influence of auto-correlation problems in the regression analysis. Regressions are estimated by OLS and $t$-statistics are adjusted for auto-correlation and heteroskedasticity using Newey-West (1987). *** and ** denotes significance at I\% and 5\% levels, respectively.

Panel A reports the results of annualized four-year return and volatility on CRSP value-weighted index over the fouryear interval. The annualized four-year returns are expressed as a percentage and are estimated using the monthly returns compiled by Schwert (1990) for the period March 1857 (the inauguration month of James Buchanan) through December 1925 and the CRSP value-weighted index for the period January 1926 through January 2005 (the month of the second inauguration of George W. Bush). The annualized four-year volatility is measured as the annualized standard deviations of returns on monthly CRSP value-weighted index over the four-year interval, expressed as a percentage. The data are obtained from CRSP.

Panel B presents the regression results of annualized four-year return and volatility on the DJIA index over four-year interval $t$. The annualized four-year returns are expressed as a percentage and are estimated using the daily DJIA index return over the period 4 March 1897 (the inauguration date of William McKinley) to 19 January 200I (the date before the second inauguration of George W. Bush). Following Leblang and Mukherjee (2005), the annualized four-year volatility is measured as the average annualized 20-day moving standard deviation of return on the daily DJIA index over the four-year interval, expressed as a percentage. The data are obtained from Global Financial Data.

a theoretical implication that poor presidential regime stock market performance is unlikely to persist.

\subsection{Reconciling the hypotheses test results with the prior presidential regime empirical literature}

The Table 6 results indicate that Democratic vs. Republican presidency return and return volatility differences are statistically indistinguishable when four-year presidential regime observations are used in the regression tests, rather than the persistent monthly or daily observations used in the recent presidential regime empirical literature (Leblang and Mukherjee, 2005; Santa-Clara and Valkanov, 2003). With the daily and monthly observations used in prior studies, the presidential regime dummy variable is highly persistent, since the dummy variable run of zeros or ones will be 
at least four years for each presidential regime. This extreme explanatory variable persistence causes the regression error term to inherit the explanatory variable persistence, and results in a violation of the ordinary least squares assumption of independently distributed regression errors. Spurious statistical relationships can be a direct result, since the standard error of the regression coefficient estimate will be biased downward, thus potentially creating a significant relationship when none is actually present (see Ferson et al., 2003; Granger and Newbold, 1974; Paye, 2006; Powell et al., 2007, 2009a, 2009b; Yule, 1926).

To determine whether presidential regime dummy variable persistence can explain why past studies have empirically documented presidential regime stock return and return volatility differentials that are not apparent in this paper's results, the daily DJIA return and return volatility sample used by Leblang and Mukherjee (2005) is utilized. The left-hand side of Panel A of Table 10 provides summary statistics for the return and return volatility data samples, and Panel B of Table 10 confirms that the presidential regime dummy presidential regime dummy variable $D D$, used as the explanatory variable in the Leblang and Mukherjee (2005) study (see regression equation (1)), is highly persistent. The first-order auto-correlation of the dummy variable $D D$ is about as extreme as is possible (0.999)! The DJIA return series also displays positive first-order auto-correlation, but at a lower level. Auto-correlation of the DJIA volatility series is very high (0.990), a finding that can be explained by overlapping observations, since a 20 -day rolling standard deviation is used by Leblang and Mukherjee (2005) to estimate volatility. The regression variable auto-correlation levels highlighted by Table 10 provide a warning of a potential spurious regression problem since, as Ferson et al. (2003) reveal, strong explanatory variable persistence combined with dependent variable persistence greatly increase the likelihood of spurious regression results.

To take account of the potentially spurious influence of presidential regime explanatory variable persistence in political regime studies, simulations can be conducted (see also Ferson et al., 2003; Powell et al., 2009b). The presidential regime dummy variable is simulated by modelling it as randomly switching between 0 and 1 according to a transition matrix that represents the probability of the Democratic or Republican Party either retaining or losing power in each presidential election (see Appendix 2, which outlines the simulation procedure, and Appendix 3 provides estimates of the presidential regime transition probabilities that are used to calibrate the presidential regime dummy variable simulation). Stock market returns or return volatility are also independently simulated using the summary statistics outlined in Panel A of Table 10, as described in Appendix 2. The simulated stock market return and return volatility series are regressed against the independently simulated presidential regime dummy variable, thus assessing the influence of spurious regression on political regime study results. The simulation procedure is therefore conducted under the assumption that the regression model dependent and independent variables are uncorrelated, while the persistence properties of the regression variables are set to match the actual data's persistence properties. Critical 5\% significance level cut-off values are thus simulated for the regression model (1) coefficient estimates, $t$-statistics, and adjusted $R^{2}$ values to determine whether the regression results obtained are within the bounds of what could be expected by chance. ${ }^{6}$

DJIA daily returns and return volatility results for presidential regime regression model (1), using the Leblang and Mukherjee (2005) sample period, are reported in Table 10. ${ }^{7}$ To assess how spurious regression bias affects the results, simulation procedure critical cut-off values for presidential regime regression model (1) are provided in Panel A of Table 10. The first row of each set of results represents the coefficient estimates, while the lower and upper confidence bound critical cut-off values for the coefficient estimates and $t$-statistics are given in the second row of each set of results.

The Democratic presidential regime dummy variable estimates for both the stock return and return volatility regressions in Panel A of Table 10 are well inside the corresponding coefficient 


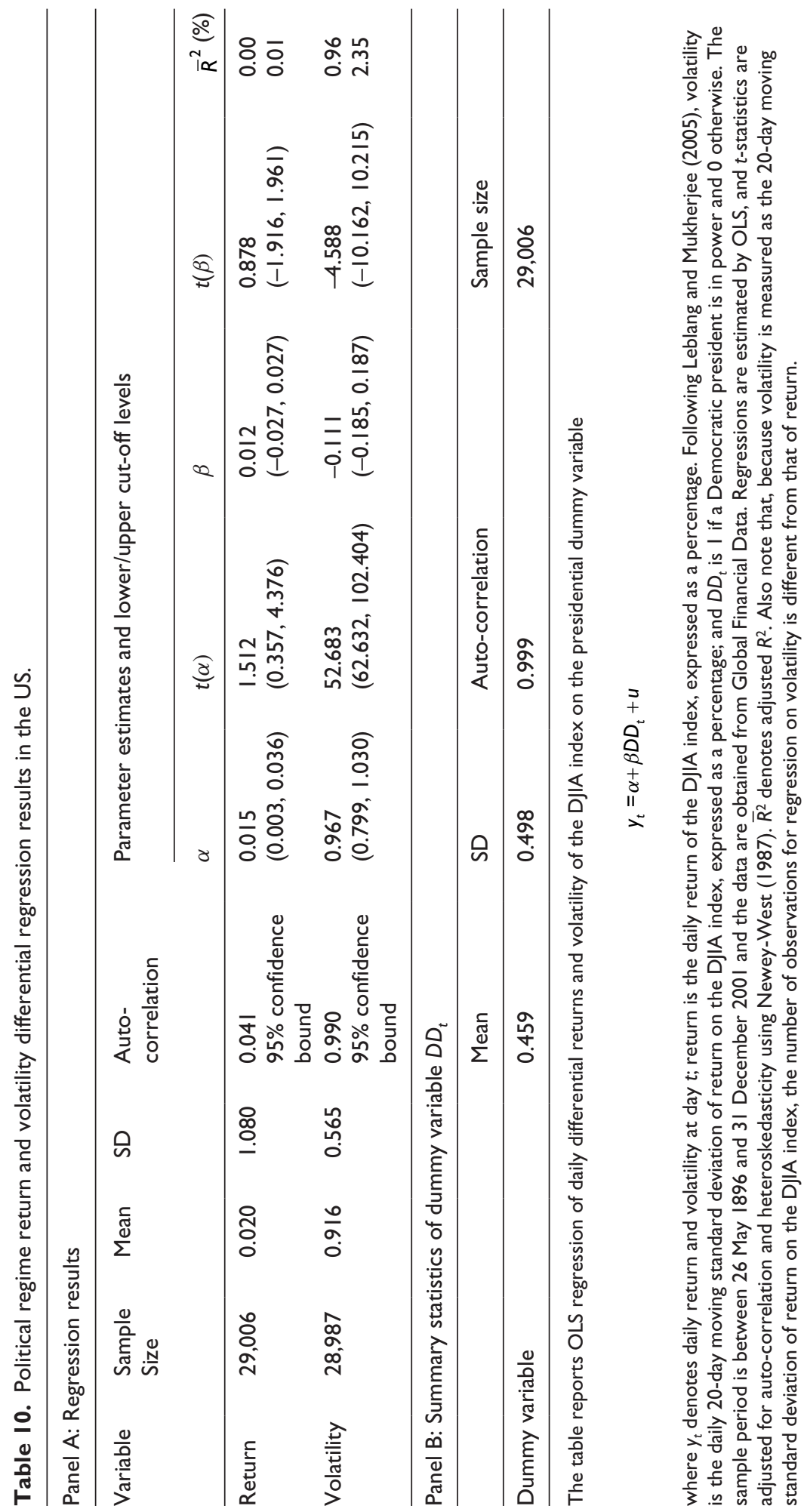


estimate $95 \%$ confidence bounds. For instance, the presidential dummy variable coefficient estimate $t$-statistic for the DJIA return series over the period 26 May 1896 to 31 December 2001 is 0.878 , an estimated value that falls well within the $95 \%$ coefficient estimate $t$-statistics confidence bounds $(-1.916,1.961)$, thus indicating that the estimated regression relationship is very likely to have occurred by chance. All the presidential regime coefficient $t$-statistic estimates in Table 8 are inside the $95 \% t$-statistic confidence bounds. The presidential dummy variable coefficient estimate $t$-statistic for the DJIA return volatility series, -4.588 , would be significant using conventional estimation procedures, but is well within the simulated $95 \%$ confidence bound $(-10.162,10.215)$, thus demonstrating that correctly accounting for regime dummy variable persistence leads to rejection of the hypotheses that volatility and returns differ across presidential regimes. ${ }^{8}$ The cut-off adjusted $R^{2}$ values reported in Panel A of Table 10 also support this conclusion. The Table 10 results therefore strongly suggest that the difference in volatility or returns under different political regimes is spurious, thus indicating that the political regime regression coefficient estimates obtained in the prior presidential literature are less than would be expected by chance.

The simulation analysis utilized in Table 10 reconciles this paper's regression results (see Table 6) with prior results documented in the presidential regime literature (see Leblang and Mukherjee, 2005; Santa-Clara and Valkanov, 2003). In particular, the regression results reported in Table 4 lead to the conclusion that, after controlling for spurious regression bias using either simulation analysis or bootstrapping, there is no significant difference in stock market returns or return volatility under different political regimes. Using daily (or monthly) data made the analysis in prior presidential regime studies unnecessarily complicated, however, since only one value of the presidential regime dummy variable is observed every four years. Only the total return and return volatility over the entire four-year presidential term are therefore relevant, so an intuitively appealing alternative is to estimate regression model (1) using four-year return or return volatility observations, as already demonstrated in this paper to directly test hypotheses 1 and 2 (see Tables 6 and 9).

As an extra sensitivity check, the DJIA return and return volatility regressions are also tested, in Table 11, using presidential regime regression model (1), within a generalized auto-regressive conditional heteroskedasticity (GARCH) regression framework (see Leblang and Mukherjee, 2005, where it is argued that it is important to test for presidential regime return differentials using GARCH since return volatility follows an auto-regressive process). The control explanatory variables used by Leblang and Mukherjee (2005) are included in the GARCH regression analysis for direct comparability with Leblang and Mukherjee (2005). The conclusion that returns and return volatility do not differ significantly across presidential regimes is unaffected by the use of GARCH regression estimation.

\subsection{Reconciling the hypotheses test results with the prior presidential regime theoretical literature}

The prior subsection reconciles this paper's test results (see Tables 6 and 9) with prior results in the presidential regime literature, thereby providing evidence in favour of this paper's theoretical arguments, implying that stock market regime differences are unlikely to be significant, and thus against the Leblang and Mukherjee (2005) theoretical model. These findings can be further reinforced by directly examining the theoretical assumptions underpinning the Leblang and Mukherjee (2005) rational expectations model of lower volatility under Democratic presidential regimes. Leblang and Mukherjee (2005) hypothesize that traders anticipate the results of elections and will expect higher inflation and lower dividend growth when Democrats are expected to win office. These assumptions are examined in Table 12 using presidential regime regression model (1), with 
Table I I. GARCH models for daily US stock return and return volatility.

\begin{tabular}{|c|c|c|c|c|}
\hline \multirow[t]{2}{*}{ Dependent variable } & \multicolumn{2}{|l|}{ Return } & \multicolumn{2}{|l|}{ Volatility } \\
\hline & Coefficient & Coefficient & Coefficient & Coefficient \\
\hline Constant & $\begin{array}{l}0.048 * * * \\
(0.011)\end{array}$ & $\begin{array}{l}0.061 * * * \\
(0.016)\end{array}$ & $\begin{array}{l}0.018 * * * \\
(0.005)\end{array}$ & $\begin{array}{l}0.017 * * * * \\
(0.004)\end{array}$ \\
\hline $\operatorname{AR}(I)$ & $\begin{array}{l}0.101 \text { **** } \\
(0.007)\end{array}$ & $\begin{array}{l}0.101 * * * \\
(0.007)\end{array}$ & $\begin{array}{l}0.974 * * * \\
(0.003)\end{array}$ & $\begin{array}{l}0.973 * * * \\
(0.003)\end{array}$ \\
\hline$D D_{t}$ & $\begin{array}{l}-0.008 \\
(0.010)\end{array}$ & $\begin{array}{l}-0.020 \\
(0.013)\end{array}$ & $\begin{array}{l}-0.005^{*} \\
(0.003)\end{array}$ & $\begin{array}{l}-0.003 \\
(0.002)\end{array}$ \\
\hline NYSE trading volume & $\begin{array}{c}0.052 \\
(0.052)\end{array}$ & $\begin{array}{l}0.093 * * \\
(0.036)\end{array}$ & $\begin{array}{l}-0.014 \\
(0.016)\end{array}$ & $\begin{array}{l}0.010 * * * \\
(0.004)\end{array}$ \\
\hline Dummy*NYSE trading volume & $\begin{array}{c}0.014 \\
(0.061)\end{array}$ & & $\begin{array}{c}0.028 \\
(0.017)\end{array}$ & \\
\hline Interest rate & $\begin{array}{l}-0.002 \\
(0.002)\end{array}$ & $\begin{array}{l}-0.001 \\
(0.003)\end{array}$ & $\begin{array}{c}0.000 \\
(0.000)\end{array}$ & $\begin{array}{c}0.000 \\
(0.000)\end{array}$ \\
\hline Divided government $(I$ = divided $)$ & & $\begin{array}{l}-0.033 \text { ** } \\
(0.016)\end{array}$ & & $\begin{array}{c}0.002 \\
(0.003)\end{array}$ \\
\hline Dates of presidential election & & $\begin{array}{c}0.181 \\
(0.256)\end{array}$ & & $\begin{array}{l}0.005 \\
(0.003)\end{array}$ \\
\hline \multicolumn{5}{|l|}{ Variance equation } \\
\hline Constant & $\begin{array}{l}0.010 \text { **** } \\
(0.001)\end{array}$ & $\begin{array}{l}0.010 * * * \\
(0.001)\end{array}$ & $\begin{array}{l}0.000 * * * \\
(0.000)\end{array}$ & $\begin{array}{l}0.000 * * * * \\
(0.000)\end{array}$ \\
\hline $\mathrm{ARCH}$ & $\begin{array}{l}0.079 * * * \\
(0.001)\end{array}$ & $\begin{array}{l}0.079 * * * \\
(0.008)\end{array}$ & $\begin{array}{l}0.074^{* * *} \\
(0.028)\end{array}$ & $\begin{array}{l}0.075 * * * \\
(0.029)\end{array}$ \\
\hline GARCH & $\begin{array}{l}0.914 * * * \\
(0.002)\end{array}$ & $\begin{array}{l}0.914 * * * \\
(0.007)\end{array}$ & $\begin{array}{l}0.933^{* * * *} \\
(0.017)\end{array}$ & $\begin{array}{l}0.933 * * * \\
(0.017)\end{array}$ \\
\hline
\end{tabular}

This table reports GARCH results on daily US stock returns and volatilities over the period 26 May I896 to 3 I December 200I. The dependent variable, daily US stock return (Return), is the daily return of the DJIA index, expressed as a percentage. Following Leblang and Mukherjee (2005), Volatility is the daily 20-day moving standard deviation of return on the DJIA index, expressed as a percentage. $D D_{t}$ is $I$ if a Democratic president is in power and 0 otherwise. NYSE trading volume (US\$bn) is expressed in billions, and interest rate is expressed as a percentage. Data for the DJIA index are obtained from Global Financial data, and NYSE trading volume (US\$bn) is obtained from NYSE. Standard errors reported in parentheses are Bollerslev and Wooldridge (1992) robust standard errors. ***, **, and * denote significance at $1 \%, 5 \%$, and $10 \%$ levels, respectively.

95\% confidence intervals in Table 12 being estimated using simulation analysis (see the left-hand side of Table 12 for the summary statistics used to calibrate the simulation analysis; see also Appendix 3). Four-year presidential regime inflation and dividend growth observations are employed in the regression analysis, thus avoiding the potential spurious regression problems that can be caused by extreme persistence of the presidential regime dummy explanatory variable if monthly observations were to be used (see the prior subsection). In Table 13, an auto-regressive 1 (AR1) presidential regime regression model is also estimated using monthly data, as an extra sensitivity check, thus reproducing the presidential regime estimation procedure employed in Leblang and Mukherjee (2005). Also as in Leblang and Mukherjee (2005), each regression model in Table 13 is estimated using GARCH estimation as well as ordinary least squares. ${ }^{9}$

The results of Tables 12 and 13 reveal that inflation is not significantly different under Democratic vs. Republican presidencies, since the presidential dummy variable coefficient estimate is well within the simulated confidence bounds in Table 12 and is also insignificant in Table 11. With a 


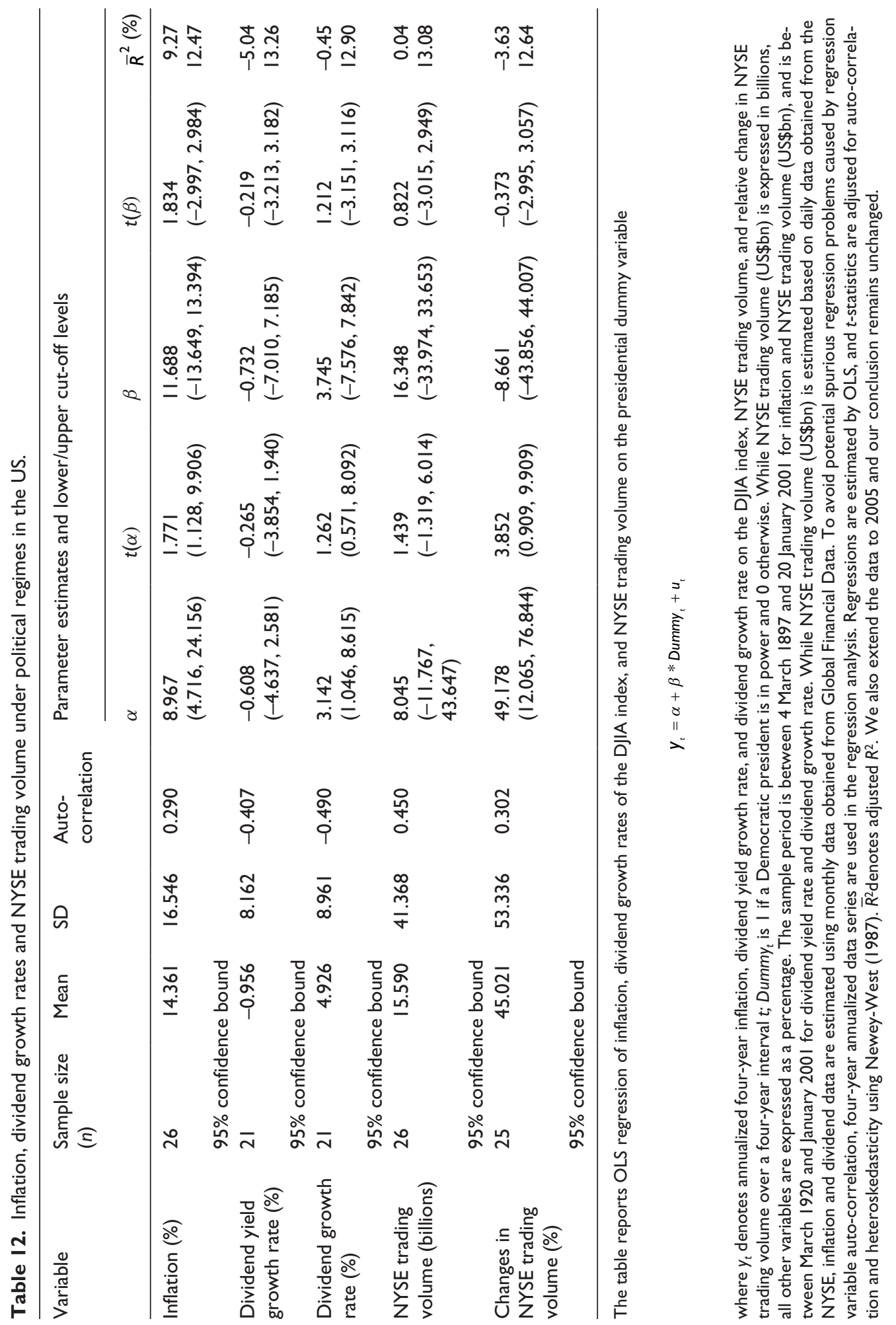


Table 13. Inflation, dividend growth rates and NYSE trading volume under political regimes using US daily and monthly data.

\section{Inflation}

(\%)
Dividend yield growth

rate (\%)
(\%)
Changes in

NYSE trading volume (\%)

Panel A: Summary statistics

\begin{tabular}{|c|c|c|c|c|c|c|c|}
\hline Mean & 43.959 & & -0.001 & & 0.004 & & 10.464 \\
\hline SD & 46.618 & & 0.061 & & 0.036 & & 220.754 \\
\hline Auto-correlation & 0.997 & & 0.068 & & -0.036 & & -0.016 \\
\hline Sample size & $\mathrm{I}, 247$ & & 971 & & 971 & & 28,774 \\
\hline & OLS & $\operatorname{GARCH}(I, I)$ & OLS & GARCH $(I, I)$ & OLS & GARCH $(I, I)$ & OLS \\
\hline
\end{tabular}

Panel B: Regression

$\begin{array}{lclccccc}\beta_{0} & -0.003 & -0.010^{* *} & -0.001 & -0.002 & 0.002 & 0.004^{* *} & 11.675^{* * *} \\ & (0.013) & (0.004) & (0.002) & (0.002) & (0.002) & (0.001) & (2.257) \\ \beta_{1} & 1.003^{* * *} & 1.003^{* * *} & 0.068 & 0.015 & -0.037 & -0.156^{* * *} & -0.016 \\ & (0.000) & (0.000) & (0.05 I) & (0.037) & (0.059) & (0.031) & (0.012) \\ \beta_{2} & 0.022 & 0.001 & 0.000 & -0.001 & 0.003 & 0.002 & -2.299 \\ & (0.021) & (0.007) & (0.004) & (0.003) & (0.003) & (0.002) & (2.374)\end{array}$

Variance equation

$\begin{array}{lccc}\text { Constant } & 0.000^{*} & 0.000^{* * *} & 0.000^{* * * *} \\ \text { ARCH } & (0.000) & (0.000) & (0.000) \\ & 0.181^{* *} & 0.081^{* * *} & 0.081^{* * *} \\ \text { GARCH } & (0.074) & (0.013) & (0.006) \\ & 0.84 I^{* * *} & 0.894^{* * *} & 0.901 * * * \\ & (0.051) & (0.015) & (0.004)\end{array}$

The table reports OLS regression as well as GARCH estimations of inflation, dividend growth rates of the DJIA index, and NYSE trading volume on the presidential dummy variable as well as the lagged dependent variable (due to the presence of auto-correlation in the data)

$$
y_{t}=\beta_{0}+\beta_{1} y_{t-1}+\beta_{2} \text { Dummy }_{t}+u_{t}
$$

where $y_{t}$ denotes inflation, dividend yield growth rate and dividend growth rate on the DJIA index, NYSE trading volume (US\$bn), and relative changes in NYSE trading volume (US\$bn); Dummy is I if a Democratic president is in power and 0 otherwise. While NYSE trading volume (US\$bn) is expressed in billions, all other variables are expressed as a percentage. The sample period is between 4 March 1897 and 20 January 200 I for daily NYSE trading volume (US\$bn). For monthly data, the sample period is between March 1897 and January $200 \mathrm{I}$ for inflation and is between March 1920 and January $200 \mathrm{I}$ for dividend yield rate and dividend growth rate. While NYSE trading volume (US\$bn) is estimated based on daily data obtained from the NYSE, inflation and dividend data are estimated using monthly data obtained from Global Financial Data. Figures in parentheses are standard errors. For regressions estimated by OLS, standard errors are adjusted for auto-correlation and heteroskedasticity using Newey-West (1987). For regression estimated by $\mathrm{GARCH}(\mathrm{I}, \mathrm{I})$, standard errors are Bollerslev and Wooldridge (1992) robust standard errors. We also extend the data to 2005 and our conclusion remains unchanged. **e*, **, and * denote significance at $1 \%, 5 \%$, and $10 \%$ levels, respectively. GARCH $(\mathrm{I}, \mathrm{I})$ is not applied to Changes in NYSE trading volume (US\$bn) due to the explosive process in the unconditional variance.

coefficient estimate of 3.745 in Table 12, the dividend growth rate is actually higher, not lower, under Democratic presidencies, although once again the difference is not statistically significant (see also Table 13). The key building blocks upon which the Leblang and Mukherjee (2005) model and presidential regime regression hypotheses are based do not seem to be borne out by the data. 
Leblang and Mukherjee (2005) further assert that share trading volume will be reduced when Democrats are expected to win office due to the anticipation of poor stock market performance. Once again, this assumption cannot be justified empirically since there is no apparent difference in trading volume between Democratic and Republican presidential regimes (see Tables 12 and 13). The rational expectations model is also dependent upon a direct connection between volume (liquidity) and return volatility. Recent research asserts an inverse (not a proportional) relationship between return volatility and liquidity (see e.g. Deuskar, 2006).

\section{Conclusion}

Political party stock market hedging considerations and political party realignment theory provide strong theoretical reasons as to why presidential regime stock market return and return volatility differences are most likely to be due to chance. Investors can hedge against political policies that could adversely affect their wealth, for instance, thus mitigating the potential effects of presidential policies on stock market performance. Presidential candidates will also find it in their own voters' interests to not repeat past policies that adversely affect the stock market and thus, either directly or indirectly, their own supporters, thus making it much less likely that poor stock market performance will persist from one presidential regime to the next president from the same party. These theoretical considerations further imply that stock market return and return volatility differentials between Democratic and Republican presidential regimes are likely to be insignificant. Both of these theoretical implications are found to be consistent with empirical tests that use extensive samples of US presidential regime observations.

To reconcile the paper's results with prior political regime literature empirical results indicating lower stock market volatility and higher returns under Democratic presidencies, the prior literature is revisited. When a simulation procedure is employed to take account of the extreme persistence properties of the presidential regime dummy variable used in previous political regime stock market studies, it becomes apparent that persistence-induced spurious regression can potentially play a very important role in these studies. The simulation procedure corrects potentially misleading statistical inference in regressions with highly persistent explanatory variables. Simulated stock market returns and return volatility are regressed against an independently generated presidential regime dummy variable series to provide an assessment of the extent to which explanatory variable persistence affects the significance of presidential regime regression analysis. The simulation procedure results indicate that the adjusted $R^{2}$ values and the coefficient estimates obtained in prior presidential regime return volatility and return difference studies are less than would be expected by chance. An important contribution of the paper is to clearly demonstrate that employing a more intuitive approach that utilizes four-year observations to test for presidential regime return, return volatility, and macroeconomic variable differences greatly improves the regression analysis model specification by reducing the potential for spurious results due to extreme explanatory variable persistence.

To theoretically reconcile the paper's results with the prior literature, it is demonstrated that the assumptions upon which a rational expectations model of higher inflation expectations under Democratic presidencies are based are not supported by the data. Specifically, investors do not trade less and would not rationally expect higher inflation and lower dividend growth under Democratic presidencies since inflation, dividend growth, and share trading volume do not differ significantly across presidential regimes. On a more fundamental level, as noted already, it is perhaps theoretically inconceivable over the longer term that either party would adhere to policies that consistently make investors worse off, since this would either directly or indirectly harm the party's own supporters. Investors' insurance activities can also protect against political parties' 
policies, especially when party policies favour or work against particular companies, thus ameliorating the net effect of presidential regimes on investors and further explaining why significant presidential regime differences are unlikely.

The paper's analysis provides a resounding answer to the question of whether stock return forecasts should be conditioned on politics, with the answer being a resounding no.

\section{Acknowledgements}

The authors are grateful to Tom Smith, Robert E. Whaley, and seminar participants at the Jiangxi University of Finance and Economics for helpful comments and suggestions.

\section{Funding}

This work was supported by Jiangxi University of Finance and Economics Innovative Research Team Development Grant.

\section{Notes}

1. Deitrick and Goldfarb (2012) report very similar findings.

2. A spurious ratio problem can also occur when both dependent and independent variables share a common divisor (see e.g. Powell et al., 2009a; Zhu, 2012).

3. This contrasts with the Gourevitch et al. (2008) model where it is assumed that only left-leaning governments adopt policies that benefit the stock market in order to spur investment and increase the demand for labour.

4. The data sample is obtained from the Federal Reserve Bank of Australia, the Australian Bureau of Statistics, and Thomson Reuters Datastream.

5. Note that just prior to the start of the sample period, William Hughes was a Labor Party politician who split from the Labor Party over conscription and was subsequently opposed by the Labor Party, so his prime ministership does not fit neatly into a Labor vs. non-Labor sample

6. As a robustness check, the analysis is repeated using a bootstrap procedure. A block sampler is used to preserve the auto-correlation of the data as well as the distribution of the data. The results provide the same interpretations as those reported in the paper and are available from the authors upon request.

7. The regression tests are repeated for the Santa-Clara and Valkanov (2003) CRSP value-weighted samples, and the (unreported) results provide the same conclusions as the DJIA results reported in Table 8 .

8. The $95 \%$ confidence bounds for the presidential regime coefficient $t$-statistic reported for the volatility series in Table 8 are very wide due to the extreme persistence properties of the daily presidential regime dummy variable (see Panel B of Table 10) as well as the volatility persistence (see Panel A of Table 10).

9. GARCH $(1,1)$ is not applied to Changes in NYSE Trading Volume due to the explosive process in the unconditional variance.

\section{References}

Bollerslev T and Wooldridge J (1992) Quasi-maximum likelihood estimation and inference in dynamic models with time-varying covariances. Econometric Reviews 11: 143-172.

Deitrick B and Goldfarb L (2012) Bulls, Bears and the Ballot Box. Charleston: Advantage Media Group.

Deuskar P (2006) Extrapolative expectations: Implications for volatility and liquidity. Unpublished Manuscript, New York University, New York.

Ferson WE, Sarkissian S and Simin TT (2003) Spurious regressions in financial Economics? Journal of Finance 58: 1393-1413.

Fowler JH (2006) Elections and markets: The effect of partisanship, policy risk, and electoral margins on the economy. Journal of Politics 68: 89-103.

Goldman E, Rocholl J and So J (2006) Does political connectedness affect firm value? Unpublished Manuscript, University of North Carolina, Chapel Hill, USA. 
Gourevitch P, Pinto PM and Weymouth S (2008) The politics of stock market development. Unpublished Manuscript, University of California-San Diego, San Diego, CA.

Granger CWJ and Newbold P (1974) Spurious regressions in economics. Journal of Econometrics 3: 111-120.

Hensel CR and Ziemba WT (1995) United States investment returns during democratic and republican administrations, 1928-1993. Financial Analysts Journal 51: 61-69.

Herbst AF and Slinkman CW (1984) Political-economic cycles in the U.S. stock market. Financial Analysts Journal 40: 38-44.

Hirsch Y and Hirsch JA (2005) Stock Trader's Almanac. Hoboken, NJ: John Wiley \& Sons.

Huang RD (1985) Common stock returns and presidential elections. Financial Analysts Journal 4: 58-61.

Knight B (2006) Are policy platforms capitalized into equity prices? Evidence from the Bush/Gore 2000 presidential election. Journal of Public Economics 90(4-5): 751-773.

Leblang D and Mukherjee B (2005) Government partisanship, elections, and the stock market: Examining American and British stock returns, 1930-2000. American Journal of Political Science 49: 780-802.

Miller G and Schofield N (2003) Activists and partisan realignments in the United States. American Political Science Review 97: 245-260.

Musto DK and Yilmaz B (2003) Trading and voting. Journal of Political Economy 111: 990-1003.

Newey WK and KD West (1987) A simple, positive semi-definite, heteroskedasticity and autocorrelation consistent covariance matrix. Econometrica 55: 703-708.

Paye BS (2006) Do macroeconomic variables predict aggregate stock market volatility? Unpublished Manuscript, Rice University, Houston, TX.

Powell JG, Shi J, Smith T, et al. (2007) The persistent presidential dummy. Journal of Portfolio Management 33: 133-143.

Powell JG, Shi J, Smith T, et al. (2009a) Common divisor, dividend yield and return predictability. International Review of Finance 9: 335-357.

Powell JG, Shi J, Smith T, et al. (2009b) Political regime, business cycles, seasonalities and returns. Journal of Banking and Finance 33: 1112-1128.

Santa-Clara P and Valkanov R (2003) The presidential puzzle: Political cycles and the stock market. Journal of Finance 58: 1841-1872.

Schofield N, Miller G and Martin A (2003) Critical elections and political realignments in the U.S.A.: 18602000. Political Studies 51: 217-240.

Schwert GW (1990) Indexes of U.S. stock prices from 1802 to 1987. Journal of Business 63: 399-426.

Snowberg EC, Wolfers J and Zitzewitz E (2006) Partisan impacts on the economy: Evidence from prediction markets and close elections. Unpublished Manuscript, Stanford University, Stanford, CA.

Twin A (2004) Surprise: Dems are better for rallies. Available at: http://money.cnn.com/2004/01/21/markets/ election_demsvreps/ (accessed 21 January 2004).

Yule GU (1926) Why do we sometimes get nonsense correlations between time series? A study in sampling and the nature of time series. Journal of the Royal Statistical Society 89: 1-64.

Zhu Y (2012) Capital structure: The case of firms issuing debt. Australian Journal of Management 37: 283-295. 


\section{Appendix I}

Table I4. History of US presidential election/inauguration dates since 1856.

\begin{tabular}{lll}
\hline President & Republican/ Election date Inauguration date \\
& Democrat & \\
& $(\mathrm{R} / \mathrm{D})$ &
\end{tabular}

\begin{tabular}{|c|c|c|c|}
\hline James Buchanan & $\mathrm{D}$ & 4 Nov 1856 & 4 Mar 1857 \\
\hline Abraham Lincoln & $\mathrm{R}$ & 6 Nov 1860 & 4 Mar I86I \\
\hline Abraham Lincoln/Andrew Johnson & $\mathrm{R}$ & 8 Nov 1864 & 4 Mar 1865 \\
\hline Ulysses S. Grant & $\mathrm{R}$ & 3 Nov 1868 & 4 Mar 1869 \\
\hline Ulysses S. Grant & $\mathrm{R}$ & 5 Nov 1872 & 4 Mar 1873 \\
\hline Rutherford B. Hayes & $\mathrm{R}$ & 7 Nov 1876 & 5 Mar 1877 \\
\hline James A. Garfield/Chester A. Arthur & $\mathrm{R}$ & 2 Nov 1880 & 4 Mar I88I \\
\hline Grover Cleveland & $\mathrm{D}$ & 4 Nov 1884 & 4 Mar 1885 \\
\hline Benjamin Harrison & $\mathrm{R}$ & 6 Nov 1888 & 4 Mar 1889 \\
\hline Grover Cleveland & $\mathrm{D}$ & 8 Nov 1892 & 4 Mar 1893 \\
\hline William McKinley & $\mathrm{R}$ & 3 Nov 1896 & 4 Mar 1897 \\
\hline William McKinley/Theodore Roosevelt & $\mathrm{R}$ & 6 Nov 1900 & 4 Mar I90I \\
\hline Theodore Roosevelt & $\mathrm{R}$ & 8 Nov 1904 & 4 Mar 1905 \\
\hline William H. Taft & $\mathrm{R}$ & 3 Nov 1908 & 4 Mar 1909 \\
\hline Woodrow Wilson & $\mathrm{D}$ & 5 Nov 1912 & $4 \operatorname{Mar} 1913$ \\
\hline Woodrow Wilson & $\mathrm{D}$ & 7 Nov 1916 & $4 \operatorname{Mar} 1917$ \\
\hline Warren G. Harding/Calvin Coolidge & $\mathrm{R}$ & 2 Nov 1920 & $4 \operatorname{Mar} 1921$ \\
\hline Calvin Coolidge & $\mathrm{R}$ & 4 Nov 1924 & $4 \operatorname{Mar} 1925$ \\
\hline Herbert Hoover & $\mathrm{R}$ & 6 Nov 1928 & 4 Mar 1929 \\
\hline Franklin D. Roosevelt & $\mathrm{D}$ & 8 Nov 1932 & 4 Mar 1933 \\
\hline Franklin D. Roosevelt & $\mathrm{D}$ & 3 Nov 1936 & 20 Jan 1937 \\
\hline Franklin D. Roosevelt & $\mathrm{D}$ & 5 Nov 1940 & 20 Jan 194I \\
\hline Franklin D. Roosevelt/Harry S. Truman & $\mathrm{D}$ & 7 Nov 1944 & 10 Jan 1945 \\
\hline Harry S. Truman & $\mathrm{D}$ & 2 Nov 1948 & 20 Jan 1949 \\
\hline Dwight D. Eisenhower & $\mathrm{R}$ & 4 Nov 1952 & 20 Jan 1953 \\
\hline Dwight D. Eisenhower & $\mathrm{R}$ & 6 Nov 1956 & 20 Jan 1957 \\
\hline John F Kennedy/Lyndon B Johnson & $\mathrm{D}$ & 8 Nov 1960 & 20 Jan 1961 \\
\hline Lyndon B. Johnson & $\mathrm{D}$ & 3 Nov 1964 & 20 Jan 1965 \\
\hline Richard M. Nixon & $\mathrm{R}$ & 5 Nov 1968 & 29 Jan 1969 \\
\hline Richard M. Nixon/Gerald R. Ford & $\mathrm{R}$ & 7 Nov 1972 & 20 Jan 1973 \\
\hline Jimmy Carter & $\mathrm{D}$ & 2 Nov 1976 & 20 Jan 1977 \\
\hline Ronald Reagan & $\mathrm{R}$ & 4 Nov 1980 & 20 Jan 1981 \\
\hline Ronald Reagan & $\mathrm{R}$ & 6 Nov 1984 & 20 Jan 1985 \\
\hline George H. Bush & $\mathrm{R}$ & 8 Nov 1988 & 20 Jan 1989 \\
\hline William J. Clinton & $\mathrm{D}$ & 3 Nov 1992 & 20 Jan 1993 \\
\hline William J. Clinton & $\mathrm{D}$ & 5 Nov 1996 & 20 Jan 1997 \\
\hline George W. Bush & $\mathrm{R}$ & 7 Nov 2000 & 20 Jan 2001 \\
\hline George W. Bush & $\mathrm{R}$ & 2 Nov 2004 & 20 Jan 2005 \\
\hline
\end{tabular}




\section{Appendix 2}

\section{A simulation test for political regime differences in stock market returns and volatility}

The dependent variable. The stock index return series $r_{t}$ is generated as a first-order auto-correlated series according to

$$
r_{t}=\alpha_{r}+\rho_{r} r_{t-1}+e_{t}
$$

for $t=2,3, \ldots, n$, where $n$ is the sample length in days, $\alpha_{r}$ is the intercept and $\rho_{r}$ is the firstorder auto-correlation coefficient. The unconditional mean and variance of the stock index series are

$$
\mu_{r}=\frac{\alpha_{r}}{1-\rho_{r}}
$$

and

$$
\sigma_{r}^{2}=\frac{\sigma_{e}^{2}}{1-\rho_{r}^{2}}
$$

where the parameter values $\mu_{r}, \sigma_{r}^{2}$, and $\rho_{r}$ are estimated from the actual stock index data (see Panel A of Table 4). The stock index series simulation is started at the unconditional mean $\mu_{r}$, and the error term for process (2) is generated from a normal distribution with a mean of zero and a variance of $\sigma_{r}^{2}\left(1-\rho_{r}^{2}\right)$. The simulated stock index series is either used directly in the simulation procedure, or transformed into a 20 -day rolling volatility series to be used in the volatility simulation procedure.

The independent variable. The independent variable series is generated independently of the simulated stock index return series. The presidential regime dummy variable is simulated by generating a presidential regime dummy explanatory variable that randomly switches between 0 and 1 according to a transition matrix that represents the probability of the Democratic or Republican Party either retaining or losing power in each presidential election. The transition matrix conditional probabilities are estimated from the actual history of US presidential election results, as provided in Appendix A, with the transition probability information for the sample period 1896 through 2001 being summarized in Appendix C. The Democratic presidential regime independent variable series $D D_{i}(i=1, \ldots, I)$ is generated as a first-order Markov chain such that the presidential regime transition probabilities at four-year election intervals are

$$
\begin{aligned}
& \operatorname{Pr}\left(D D_{i}=0 \mid D D_{i-1}=0\right)=q \\
& \operatorname{Pr}\left(D D_{i}=1 \mid D D_{i-1}=0\right)=1-q
\end{aligned}
$$




$$
\begin{aligned}
& \operatorname{Pr}\left(D D_{i}=1 \mid D D_{i-1}=1\right)=p \\
& \operatorname{Pr}\left(D D_{i}=0 \mid D D_{i-1}=1\right)=1-p
\end{aligned}
$$

where the subscript $i$ represents presidential inauguration dates and $I$ is the total number of elections in the sample. Probability $p$ represents the probability of a Democratic president winning at the next presidential election when a Democratic administration is already in power, whereas probability $q$ represents the probability of Republicans retaining presidential office. The presidential regime dummy variable value is set at the presidential inauguration date and stays the same during all the days of the presidential term. The simulated presidential regime series starting value $D D_{i=0}$ is generated according to the unconditional probability of a Democratic presidency occurring during the sample period.

Simulated cut-offs for spurious regression bias. To obtain simulated critical 95\% cut-off values, a dependent variable and an uncorrelated independent variable series are simulated for a time period equal to the return series sample periods, and a regression is then run on the simulated series using presidential return or return volatility regression model (1). The process is repeated 10,000 times, with the coefficient estimates, $t$-statistics and adjusted $R^{2}$ values from each simulated regression being recorded and ranked from lowest to highest. The 95th percentile adjusted $R^{2}$ (i.e. the cutoff $R^{2}$ ) as well as the 2.5th and 97.5th percentile coefficient estimates and $t$-statistics provide the 5\% critical cut-off values. The $5 \%$ critical cut-off values serves as a benchmark for assessing the statistical significance of the estimated regression results obtained using the original data to determine whether the results are likely to be due to chance (see also Ferson et al., 2003; Powell, 2007, 2009a, 2009b).

\section{Appendix 3}

\begin{tabular}{|c|c|c|c|c|c|}
\hline & \multicolumn{2}{|l|}{ Republican } & \multicolumn{2}{|l|}{ Democrat } & \multirow{2}{*}{$\frac{\text { Frequency }}{\text { Total }}$} \\
\hline & Frequency & $\begin{array}{l}\text { Transition } \\
\text { probability } \\
(\%)\end{array}$ & Frequency & $\begin{array}{l}\text { Transition } \\
\text { probability } \\
(\%)\end{array}$ & \\
\hline Republican & 15,663 & 99.96 & 5 & 0.04 & 15,668 \\
\hline Democrat & 6 & 0.04 & 13,313 & 99.96 & 13,319 \\
\hline Total & 15,669 & 54.05 & 13,318 & 45.95 & 28,987 \\
\hline
\end{tabular}

Table I5. Transition probabilities of the daily dummy variable. 